ISSN 2075-1729

www.mdpi.com/journal/life

Review

\title{
Biohydrogen Production by the Thermophilic Bacterium Caldicellulosiruptor saccharolyticus: Current Status and Perspectives
}

\author{
Abraham A. M. Bielen *, Marcel R. A. Verhaart, John van der Oost and Servé W. M. Kengen \\ Laboratory of Microbiology, Wageningen University, Dreijenplein 10, 6703 HB Wageningen, \\ The Netherlands; E-Mails: verhaart@biogast.nl (M.R.A.V.); john.vanderoost@wur.nl (J.O.); \\ serve.kengen@wur.nl (S.W.M.K.) \\ * Author to whom correspondence should be addressed; E-Mail: bram.bielen@wur.nl; \\ Tel.: +31-317-482-105; Fax: +31-317-483-829.
}

Received: 5 December 2012; in revised form: 6 January 2013 / Accepted: 7 January 2013 / Published: 17 January 2013

\begin{abstract}
Caldicellulosiruptor saccharolyticus is one of the most thermophilic cellulolytic organisms known to date. This Gram-positive anaerobic bacterium ferments a broad spectrum of mono-, di- and polysaccharides to mainly acetate, $\mathrm{CO}_{2}$ and hydrogen. With hydrogen yields approaching the theoretical limit for dark fermentation of 4 mol hydrogen per mol hexose, this organism has proven itself to be an excellent candidate for biological hydrogen production. This review provides an overview of the research on $C$. saccharolyticus with respect to the hydrolytic capability, sugar metabolism, hydrogen formation, mechanisms involved in hydrogen inhibition, and the regulation of the redox and carbon metabolism. Analysis of currently available fermentation data reveal decreased hydrogen yields under non-ideal cultivation conditions, which are mainly associated with the accumulation of hydrogen in the liquid phase. Thermodynamic considerations concerning the reactions involved in hydrogen formation are discussed with respect to the dissolved hydrogen concentration. Novel cultivation data demonstrate the sensitivity of C. saccharolyticus to increased hydrogen levels regarding substrate load and nitrogen limitation. In addition, special attention is given to the rhamnose metabolism, which represents an unusual type of redox balancing. Finally, several approaches are suggested to improve biohydrogen production by $C$. saccharolyticus.
\end{abstract}


Keywords: Caldicellulosiruptor saccharolyticus; biohydrogen; dark fermentation; cellulolytic thermophile; thermodynamics; rhamnose metabolism; pyrophosphate; redox balance; hydrogen inhibition; regulation

\section{Introduction}

The use of renewable plant biomass for the production of biofuels, chemicals or other biocommodities can provide a realistic alternative for fossil fuel based processes [1,2]. The implementation of lignocellulosic biomass for biofuel production requires the degradation of recalcitrant substrates like cellulose, hemicellulose or lignin. Lignin is either removed or modified [3], while cellulose and hemicellulose are converted into more readily fermentable mono-, di- and oligo-saccharides. Although this can be achieved by different (thermo)chemical or enzymatic pre-treatments, a more desirable process combines both substrate hydrolysis and fermentation of complex plant biomass. Such a "consolidated bioprocess" (CBP) circumvents the negative environmental impact inherent to (thermo)chemical pre-treatment and might limit overall process costs $[1,4]$.

Hydrogen gas $\left(\mathrm{H}_{2}\right)$ is considered an alternative for the non-renewable fossil fuels and can be produced in a carbon neutral process. The controlled biological production of $\mathrm{H}_{2}$ would allow for capturing the $\mathrm{CO}_{2}$ released during the process, preventing it to dissipate into the environment. In addition, compared to carbon based (bio)fuel types, $\mathrm{H}_{2}$ has the advantage that (i) during its oxidation only $\mathrm{H}_{2} \mathrm{O}$ is released and (ii) that $\mathrm{H}_{2}$ fuel cells can be used, which are more energy efficient than the presently used combustion engines [5]. Biohydrogen can be produced from renewable feedstocks in an anaerobic fermentation process, which is often referred to as dark fermentation to distinguish it from photofermentative hydrogen production.

Both plant biomass degradation and biological $\mathrm{H}_{2}$ formation appear advantageous under thermophilic conditions. Moreover, thermophiles display an extensive glycoside hydrolase inventory aiding in the lignocellulosic biomass breakdown [6-8]. Based on thermodynamic considerations $\mathrm{H}_{2}$ formation is more feasible at elevated temperatures [9,10]. Correspondingly, $\mathrm{H}_{2}$ yields are in general higher for (hyper)thermophiles, reaching the theoretical limit of $4 \mathrm{~mol} \mathrm{H}_{2}$ per mol of hexose, compared to the mesophilic hydrogen producers $[9,11,12]$.

Since its isolation in the mid-eighties it has become clear that the thermophilic anaerobic bacterium Caldicellulosiruptor saccharolyticus [13] displays both the desirable polysaccharide degrading capabilities (including cellulose) and $\mathrm{H}_{2}$ producing characteristics, making it an outstanding source for thermostable glycoside hydrolases and an excellent candidate for biohydrogen production from renewable biomass.

This review will discuss the available scientific data on $C$. saccharolyticus regarding its lignocellulolytic capability, substrate specificity, catabolism and $\mathrm{H}_{2}$ producing capacity, which has made $C$. saccharolyticus to become a model organism for the study of fermentative hydrogen formation at elevated temperatures. 


\section{Isolation and Initial Characterization}

The foreseen commercial value of thermostable cellulolytic enzymes in biotechnological applications triggered the investigation of new sources of these types of enzymes. In the search for novel thermophilic cellulolytic micro-organisms, several anaerobic bacteria have been isolated from natural enrichment sites from the Rotorua-Taupo thermal area in New Zealand [14]. One of the isolated strains, TP8.T 6331 [14] also referred to as TP8 [15] or "Caldocellum saccharolyticum" [16], revealed thermostable cellulase activity up to $85{ }^{\circ} \mathrm{C}[14,15]$ but also lignocellulolytic biomass decomposition capabilities [16]. Strain TP8.T 6331 was assigned to a new genus Caldicellulosiruptor as Caldicellulosiruptor saccharolyticus and was characterized as a Gram-positive, asporogenous, extremely thermophilic and strictly anaerobic bacterium capable of sustaining growth at a temperature range of $45-80{ }^{\circ} \mathrm{C}\left(\mathrm{T}_{\mathrm{opt}}=70{ }^{\circ} \mathrm{C}\right)$ and $\mathrm{pH}$ range of 5.5-8.0 $\left(\mathrm{pH}_{\mathrm{opt}}=7\right)$ [13]. Acid production could be detected for a broad substrate range including different pentoses and hexoses, di-saccharides and polysaccharides like cellulose and xylan [13-16]. In particular, the capacity to use cellulose at high temperatures was exceptional.

Ever since, several cellulolytic and weakly cellulolytic Caldicellulosiruptor species have been identified, all of which are isolated from terrestrial geothermal regions. [13,14,17-28]. The availability of the fully sequenced genomes of 8 of these Caldicellulosiruptor species allows the investigation of the possible differences in their cellulolytic traits and the analysis of other remarkable features of this genus [29-33].

\section{Hydrolytic Capacity and Complex Biomass Decomposition}

For the decomposition of recalcitrant plant polysaccharides C. saccharolyticus does not employ cellulosome-like structures, as described for some Clostridium species [34], but wields a variety of free-acting endo- and exo-glycoside hydrolases $(\mathrm{GH})$ capable of hydrolyzing the glycosidic bonds of $\alpha$ - and $\beta$-glucans like starch, pullulan and cellulose, but also xylan and hetero-polysaccharides like hemicelluloses and pectin $[8,13,33,35,36]$. Actually, Caldicellulosiruptor species, together with Thermoanaerobacter species, are one of the most thermophilic crystalline cellulose-degrading organisms known to date that use free-acting primary cellulases [7]. C. saccharolyticus contains 59 open reading frames (ORFs) that include GH catalytic domains [29]. Some of these ORFs code for multifunctional, multi-domain proteins that contain glycoside hydrolase domains, belonging to different GH families, and multiple carbon binding modules [6,29,36]. The catalytic properties and structural organization of some of the glycoside hydrolases from $C$. saccharolyticus, have been extensively investigated.

A $\beta$-glucosidase (BglA) [37,38], $\beta$-xylosidase [39], $\beta$-1,4-xylanase [40] and a type I pullulanase [41] from $C$. saccharolyticus have been cloned into $E$. coli and characterized. The majority of the genes encoding xylan degradation associated enzymes appear to be clustered on the genome ( $x y n B-x y n F$, Csac_2404-2411) [6,36]. Both XynA and XynE exhibit endoxylanase and xylosidase activity [36,42], while XynB only acts as a $\beta$-D-xylosidase [43]. XynC does not contain a GH domain and was shown to be an acetyl esterase [44], XynD showed to be active on xylan [36] and although the cloning and expression of intact multi-domain XynF could not be achieved, its $N$ - and $C$-terminal parts revealed 
catalytic activity on arabinoxylan. Hence XynF was proposed to be involved in the degradation of the arabinoxylan component of hemicellulose [36]. A second locus covers several genes coding for multidomain proteins involved in glucan and mannan hydrolysis (celA-manB, Csac_1076-1080) [6,36]. CelA is coding for a multidomain cellulase [45], the bifunctional cellulase CelB exhibited both endo- $\beta$-1,4-glucanase and exo- $\beta$-1,4-glucanase activity [36,46,47] and CelC was characterized as an endo-1,4- $\beta$-D-glucanase [48]. ManA was characterized as a $\beta$-mannanase [49], but ManB codes for an inactive mannase, which after correcting for a frame shift in the nucleotide sequence, exhibited $\beta$-mannanase activity [48]. Several ORFs of the described celA-manB and $x y n B$-xynF loci were differentially transcribed on pretreated poplar and switch grass compared to the monosaccharides glucose and xylose, showing their involvement in the decomposition of complex carbohydrates [36].

While some of the GH proteins act intracellularly, others are excreted, allowing the decomposition of non-soluble substrates to smaller oligo- or mono-saccharides. Early findings by Reynolds et al. already indicated that a significant percentage of the cellulolytic activity was found to be associated with insoluble substrate [15]. These interactions, between GH and substrate, are facilitated by carbon binding modules (CBM). CBMs allow the positioning of the GH catalytic domains in the vicinity of the substrate, thus increasing the rate of catalysis. Interestingly, most multi-domain GHs identified in C. saccharolyticus, containing one or more CBMs, possess a signal peptide, which mark them for excretion [36]. A relative higher amount of GH related proteins could be observed in the substrate bound protein fraction, from Caldicellulosiruptor species grown on Avicel, with respect to the whole cell proteome [29]. Additionally, these proteome studies allowed the identification of specific GHs which interact with crystalline cellulose. CelA, a multi-domain GH consisting of two GH domains (GH9 and GH48) and three CBM3 modules, was found to be the most abundant substrate bound protein for strong cellulolytic Caldicellulosiruptor species [29]. The sequenced genomes of Caldicellulosiruptor species reveal differences in glycoside hydrolytic capacity, which reflects their difference in biomass degrading capabilities $[29,35]$. The secretome of $C$. saccharolyticus grown on glucose contains several carbohydrate-degrading enzymes including CelA, ManA, CelB and CelC (protein sequence ID A4XIF5/6/7/8 respectively), which indicates that these GH are constitutively expressed even under non-cellulose degrading conditions [50].

In addition to the interactions between substrate and glycoside hydrolases, interactions between whole cells and a substrate have also been observed for C. saccharolyticus. These interactions appeared to be substrate specific. For instance, a higher degree of cell-to-substrate attachment was observed for cells grown on switch grass, compared to poplar [36]. Several S-layer homology (SLH) domain containing proteins, which have been identified in Caldicellulosiruptor species, are proposed to have a role in such cell substrate interactions. These SLH domain proteins contain both glycoside hydrolases domains and non-catalytic carbohydrate binding domains, which are utilized in lignocellulose degradation by both recruiting and degrading complex biomass via cell substrate interactions [51]. In addition, cell immobilization on a support matrix, like pine wood shavings, supports cell survival and improves the $\mathrm{H}_{2}$ evolving capacity of C. saccharolyticus [52]. 


\section{Sugar Catabolism and Pathway Regulation}

\subsection{Sugar Uptake and Fermentation}

Soluble sugar substrates can enter C. saccharolyticus cells either as mono-, di- or oligo-saccharides via several $A B C$-transporters, which facilitate substrate transport across the membrane at the expense of ATP. In addition, C. saccharolyticus contains one fructose specific phosphotransferase system (PTS). During PTS-mediated transport the substrate is both transported and phosphorylated at the expense of phosphoenolpyruvate (PEP). The substrate specificity of the 24 sugar ABC transport systems, identified in C. saccharolyticus, has been assigned based on bioinformatic analysis and functional genomics [53]. Most of the identified ABC transporters have a broad predicted substrate specificity and for some transporters the annotated substrate specificity was confirmed by transcriptional data obtained from cells grown on different mono-saccharides [53]. Some substrates can be transported by multiple transporter systems (Figure 1).

The growth of $C$. saccharolyticus on sugar mixtures revealed the co-utilization of hexoses and pentoses, without any signs of carbon catabolite repression (CCR) $[33,53]$. The absence of CCR is in principle a very advantageous characteristic of $C$. saccharolyticus, as it enables the simultaneous fermentation of hexoses and pentoses [33]. Substrate co-utilization has also been confirmed for biomass derived hydrolysates [54,55]. Despite the absence of CCR, a somewhat higher preference for the pentose sugars (xylose and arabinose) with respect to the hexose sugars (glucose, mannose and galactose) was demonstrated, but the highest preference was observed for the PTS-transported hexose fructose [53].

Once inside the cell, the sugar substrates are converted into a glycolytic intermediate. NMR analysis of the fermentation end-products of $C$. saccharolyticus grown on ${ }^{13} \mathrm{C}$-labeled glucose showed that the Embden-Meyerhof pathway is the main route for glycolysis [56]. All genes encoding components of the Embden-Meyerhof and non-oxidative pentose phosphate pathway have been identified in the genome. There is no evidence for the presence of the oxidative branch of the pentose phosphate pathway or the Entner-Doudoroff pathway [33] (Figure 1).

Each sugar substrate, with the exception of rhamnose is completely catabolized to glyceraldehyde 3-phosphate (GAP) (rhamnose catabolism will be discussed separately in more detail below). The subsequent conversion of GAP to pyruvate, via the C-3 part of glycolysis, results in the formation of the reduced electron carrier NADH. Pyruvate can be further oxidized to acetyl-CoA by pyruvate: ferredoxin oxidoreductase (POR), which is coupled to the generation of reduced ferredoxin $\left(\mathrm{Fd}_{\mathrm{red}}\right)$. Finally, acetyl-CoA can be converted to the fermentation end-product acetate (Figure 1).

Both types of reduced electron carriers ( $\mathrm{NADH}$ and $\mathrm{Fd}_{\mathrm{red}}$ ) can be used by hydrogenases for proton reduction, thus forming $\mathrm{H}_{2}$. The genome of $C$. saccharolyticus contains a gene cluster coding for an NADH-dependent cytosolic hetero-tetrameric Fe-only hydrogenase (hyd) and a cluster encoding a membrane bound multimeric [NiFe] hydrogenase (ech), which presumably couples the oxidation of $\mathrm{Fd}_{\text {red }}$ to $\mathrm{H}_{2}$ production [33]. Under optimal cultivation conditions, when all reductants are used for $\mathrm{H}_{2}$ formation, the complete oxidation of glucose yields $4 \mathrm{~mol}$ of $\mathrm{H}_{2}$ per mol of glucose consumed (Equation 1). 
Figure 1. Overview of the central carbon metabolism of Caldicellulosiruptor saccharolyticus.

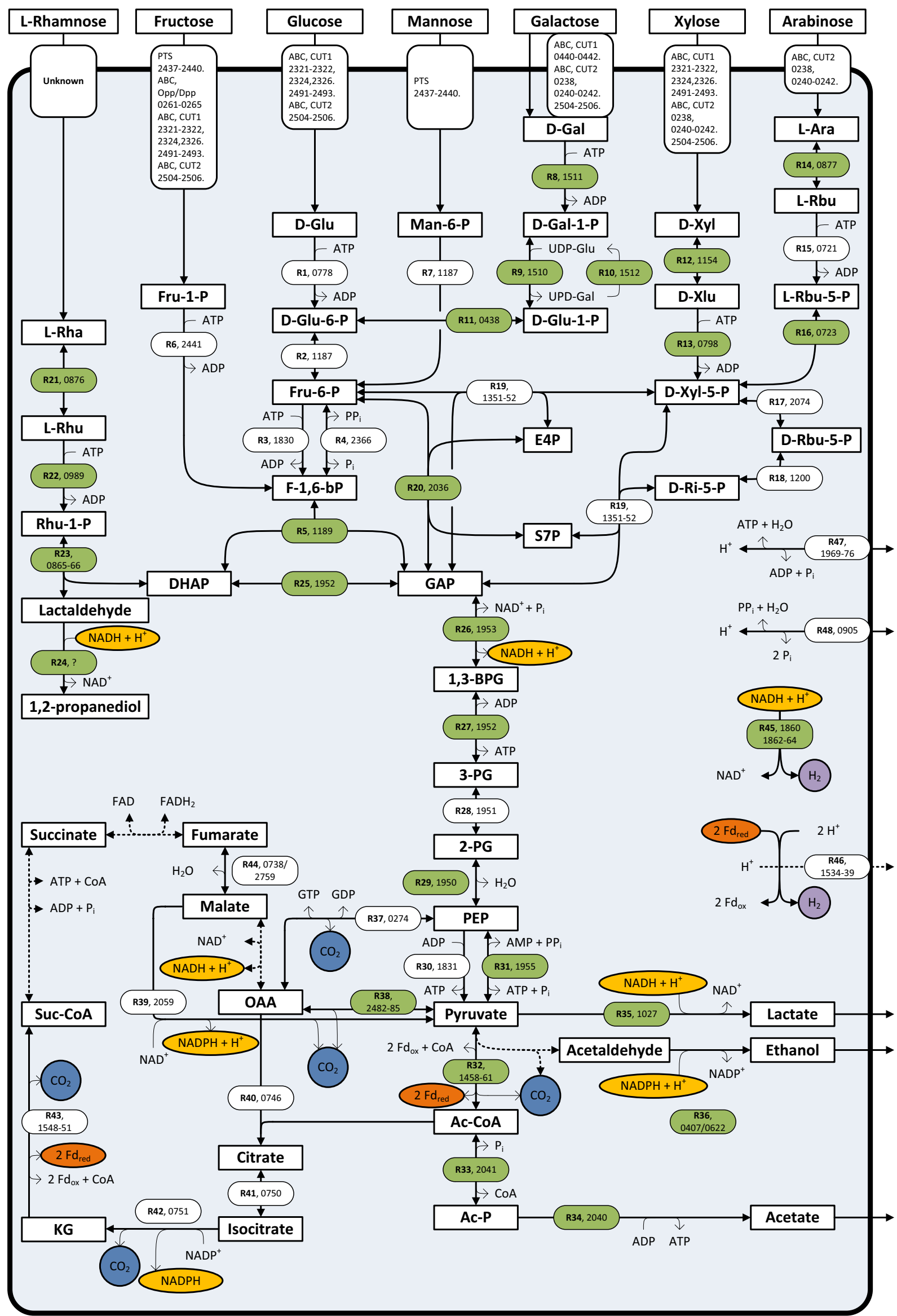


Figure 1. Cont.

During sugar catabolism electron carriers $\left(\mathrm{NAD}^{+}\right.$and $\left.\mathrm{Fd}_{\mathrm{ox}}\right)$ are reduced. These reduced electron carriers can be re-oxidized by hydrogenases to form $\mathrm{H}_{2}$ (reaction 45 and 46). For each reaction (numbered) the locus tags of the associated genes are given. When given in green they have been shown to be regulated by a specific mono-saccharide $[33,53]$. Dotted lines: no candidate genes can be identified. Reactions: R1, glucokinase, EC 2.7.1.2; R2, phosphoglucose isomerase, EC 5.3.1.9; R3, ATP-dependent 6-phosphofructokinase, EC 2.7.1.11; R4, PPi-dependent 6-phosphofructokinase, EC 2.7.1.90; R5, fructose-bisphosphate aldolase, EC 4.1.2.13; R6, 1-phosphofructokinase, EC 2.7.1.56; R7, phosphomannose isomerase, EC 5.3.1.8; R8, galactokinase, EC 2.7.1.6; R9, galactose 1-phosphate uridyl transferase, EC 2.7.7.12; R10, UDP-galactose 4-epimerase, EC 5.1.3.2; R11, phosphoglucomutase, EC 5.4.2.6; R12, D-xylose isomerase, EC 5.3.1.5; R13, xylulokinase, EC 2.7.1.17; R14, L-arabinose isomerase, EC 5.3.1.4; R15, L-ribulokinase, EC 2.7.1.16; R16, L-xylulose 5-phosphate 3-epimerase, EC 5.1.3.22; R17, ribulose-phosphate 3-epimerase, EC 5.1.3.1; R18, ribose-5-phosphate isomerase, EC 5.3.1.6; R19, transketolase, EC 2.2.1.1; R20, transaldolase, EC 2.2.1.2; R21, L-rhamnose isomerase, EC 5.3.1.14; R22, L-rhamnulose kinase, EC 2.7.1.5; R23, L-rhamnulose-1-phosphate aldolase, EC 4.1.2.19; R24, L-1,2-propanediol oxidoreductase, EC 1.1.1.77; R25, triose phosphate isomerase, EC 5.3.1.1; R26, glyceraldehyde-3-phosphate dehydrogenase, EC 1.2.1.12; R27, phosphoglycerate kinase, EC 2.7.2.3; R28, phosphoglycerate mutase, EC 5.4.2.1; R29, phosphopyruvate hydratase (enolase), EC 4.2.1.11; R30, pyruvate kinase, EC 2.7.1.40; R31, pyruvate phosphate dikinase, EC 2.7.9.1; R32, pyruvate:ferredoxin oxidoreductase, EC 1.2.7.1; R33, phosphotransacetylase, EC 2.3.1.8; R34, acetate kinase, EC 2.7.2.1; R35, L-lactate dehydrogenase, EC 1.1.1.27; R36, alcohol dehydrogenase, EC 1.1.1.1; R37, phosphoenolpyruvate carboxykinase, 4.1.1.32; R38, oxaloacetate decarboxylase $\left(\mathrm{Na}^{+} \mathrm{Pump}\right)$, EC 4.1.1.3; R39, malic enzyme 1.1.1.40; R40, citrate synthase, EC 2.3.3.1; R41, aconitase, EC 4.2.1.3; $\mathbf{R 4 2}$, isocitrate dehydrogenase, EC 1.1.1.42; R43, 2-oxoglutarate:ferredoxin oxidoreductase, EC 1.2.7.3; R44, fumarase, EC 4.2.1.2; R45, NADH-dependent Fe-only hydrogenase (hyd); R46, ferredoxin-dependent [NiFe] hydrogenase (ech); R47, $\mathrm{H}^{+}$-ATPase, EC 3.6.3.14; R48, V-type $\mathrm{H}^{+}$-translocating pyrophosphatase. Abbreviations: D-Glu, D-Glucose; D-Glu-6-P, D-Glucose-6-phosphate; Fru-6-P, Fructose-6-phosphate; F-1,6-bP, Fructose-1,6-bisphosphate; Fru-1-P, Fructose-1-phosphate; Man-6-P, Mannose-6-phosphate; D-Gal, D-Galactose; D-Gal-1-P, D-Galactose-1-phosphate; D-Glu-1-P, D-Glucose-1-phosphate; D-Xyl, D-Xylose; D-Xlu, D-Xylulose; D-Xyl-5-P, Xylulose 5-phosphate; L-Ara, L-Arabinose; L-Rbu, L-Ribulose; Rbu-5-P, L-Ribulose-5-P; D-Rbu-5-P, D-Ribulose-5-phosphate; D-Ri-5-P, D-Ribose-5-P; E4P, D-Erythrose 4-phosphate; S7P, D-Sedoheptulose-7-phosphate; DHAP, Dihydroxyacetone phosphate; GAP, Glyceraldehyde 3-phosphate; 1,3-BPG, 1,3-Bisphosphoglycerate; 3-PG, 3-Phosphoglycerate; 2-PG, 2-Phosphoglycerate; PEP, Phosphoenolpyruvate; Ac-CoA, Acetyl-CoA; Ac-P, Acetyl phosphate; OAA, Oxaloacetate; KG, 2-Oxoglutarate; Suc-CoA, Succinyl-CoA; $\mathrm{H}_{2} \mathrm{O}$, Water; $\mathrm{H}^{+}$, Proton; $\mathrm{H}_{2}$, Hydrogen; $\mathrm{CO}_{2}$, Carbon dioxide; $\mathrm{Fd}_{\mathrm{ox}}$ oxidized Ferredoxin; $\mathrm{Fd}_{\text {red }}$ reduced Ferredoxin; $\mathrm{NADP}^{+}$, Nicotinamide adenine dinucleotide phosphate; NADPH, reduced Nicotinamide adenine dinucleotide phosphate; $\mathrm{NAD}^{+}$, Nicotinamide adenine dinucleotide; $\mathrm{NADH}$, reduced Nicotinamide adenine dinucleotide; FAD, Flavin adenine dinucleotide; $\mathrm{FADH}_{2}$, reduced Flavin adenine dinucleotide; ATP, Adenosine triphosphate; ADP, Adenosine diphosphate; AMP, Adenosine monophosphate; GTP, Guanosine triphosphate; GDP, Guanosine diphosphate; $\mathrm{PP}_{\mathrm{i}}$, pyrophosphate; $\mathrm{P}_{\mathrm{i}}$, inorganic phosphate; CoA, Coenzyme A; UPD-Glu, UDP-Glucose; UDP-Gal, UPD-Galactose. 


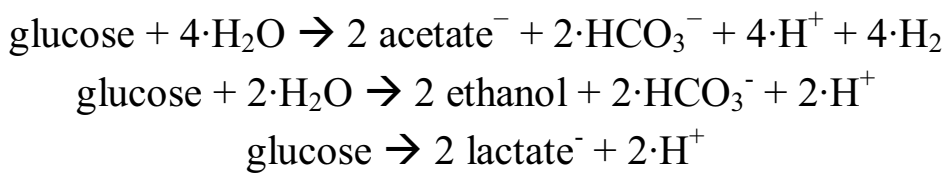

However, suboptimal growth conditions lead to a mixed acid fermentation with ethanol (Equation 2) and lactate (Equation 3) as end products in addition to acetate and $\mathrm{H}_{2}$. Lactate is produced from pyruvate, using NADH as electron donor and catalyzed by lactate dehydrogenase (LDH). The corresponding $l d h$ gene could be easily identified in the genome $[33,57]$. However, the identity of the enzymes and genes involved in ethanol formation, are less clear. Two alcohol dehydrogenase (ADH) genes have been identified in the genome which, based on transcriptional data, can both be involved in ethanol formation from acetaldehyde. The way acetaldehyde is produced, is however, not known. Acetaldehyde can be produced from pyruvate by a pyruvate decarboxylase, as described for yeast, or from acetyl-CoA by an acetaldehyde dehydrogenase, as is commonly seen in fermentative bacteria. In several thermophilic ethanol-producing bacteria, acetaldehyde is produced by a bifunctional acetaldehyde/ethanol dehydrogenase [58,59]. However, no candidate gene could be identified for any of these alternatives $[33,60]$. A third option might be that acetaldehyde is formed from pyruvate in a CoA-dependent side reaction of the pyruvate:ferredoxin oxidoreductase as described for Pyrococcus furiosus [61]. There is no experimental evidence for such a side reaction in C. saccharolyticus, but the absence of a dedicated enzymatic acetaldehyde-forming step might explain the low ethanologenic capacity of $C$. saccharolyticus. The difference in the observed lower ethanol to acetate ratio for C. saccharolyticus with respect to Clostridium thermocellum [16] can be explained by the fact that the C. saccharolyticus genome does not have a similar pathway for ethanol formation as identified in C. thermocellum [58]. Similar to other high yield ethanol-producing thermophiles, like Thermoanaerobacter ethanolicus [62] or Thermoanaerobacterium saccharolyticum [63], Clostridium thermocellum has a bifunctional acetaldehyde-CoA/alcohol dehydrogenase, which catalyzes ethanol formation from acetyl-coA [58,59]. Such a pathway is absent in low level ethanol-producing thermophiles like C. saccharolyticus [33], Thermoanaerobacter tengcongensis [64] and Pyrococcus furiosus [65]. Although C. saccharolyticus is able to produce some ethanol, the flux through the ethanol-forming pathway is apparently limited resulting in the lower ethanol to acetate ratio.

$\mathrm{NADPH}$ is assumed to be the preferred substrate for the ethanol-forming ADH reaction [33,57]. A potential source of NAPDH could be the isocitrate dehydrogenase in the oxidative branch of the incomplete TCA cycle (Figure 1). Alternatively, NADPH can be produced from NADH, but so far no candidate genes coding for such transhydrogenase have been identified in C. saccharolyticus $[33,60]$. With respect to $\mathrm{H}_{2}$ production, it is important to realize that only the production of acetate is coupled to $\mathrm{H}_{2}$ formation since no net reducing power remains for $\mathrm{H}_{2}$ formation when ethanol or lactate is produced.

\subsection{Rhamnose Fermentation}

Compared to glucose, fermentative growth on the deoxy sugar rhamnose is associated with a different carbon and electron metabolism. The proposed pathway for rhamnose degradation (Figure 1) implies that during rhamnose catabolism half of the generated reduced electron-carriers is used for the reduction of lactaldehyde to 1,2-propanediol, while the other half can be recycled through $\mathrm{H}_{2}$ formation [33]. Indeed, fermentation of rhamnose by C. saccharolyticus results in the production of 
1,2-propanediol, acetate, $\mathrm{H}_{2}$ and $\mathrm{CO}_{2}$ in a 1:1:1:1 ratio ([66], Figure 2a). This ratio suggests that all $\mathrm{NADH}$ is used for 1,2-propanediol formation and that all $\mathrm{Fd}_{\mathrm{red}}$ is used for $\mathrm{H}_{2}$ formation. However, when $C$. saccharolyticus is grown on rhamnose under a headspace of carbon monoxide (CO), which is an established competitive inhibitor of both NiFe- [67] and Fe-only [68] hydrogenases, $\mathrm{H}_{2}$ evolution is significantly inhibited ([66], Figure 2b). The CO cultivation condition does not affect 1,2-propanediol formation, but less $\mathrm{H}_{2}$ is produced and the remaining reduced electron-carriers are now recycled by the formation of lactate and ethanol, consequently leading to a decrease in the acetate level. These findings suggest that, based on the substrate specificity of the lactate dehydrogenase (NADH, [57]) and the ethanol dehydrogenase(s) (NADPH, [57]), electron exchange between the $\mathrm{Fd}_{\text {red }}$ and $\mathrm{NAD}(\mathrm{P})^{+}$is required. However, no genes have been identified in $C$. saccharolyticus coding for an enzyme capable of catalyzing such a reaction $[33,60]$. Transcript levels of the genes from the gene cluster containing both the L-rhamnose isomerase and L-rhamnulose-1-phosphate aldolase are highly upregulated during growth on rhamnose (Figure 3) [33]. Although the function of the other genes in the cluster with respect to rhamnose catabolism remains unclear, the absence of such gene cluster and the rhamnose kinase gene from the genome of other Caldicellulosiruptor species, strongly correlates with their inability of rhamnose degradation (Table 1). This difference in rhamnose degrading capability between Caldicellulosiruptor species reflects the open nature of the Caldicellulosiruptor pan genome [29].

Figure 2. Fermentation profile of $C$. saccharolyticus grown on rhamnose batch cultivation: (a) without CO in the headspace (b) with a 100\% CO headspace. Rhamnose (diamonds), acetate (open triangles), 1,2 propanediol (asterisks), lactate (open squares), ethanol (crosses), $\mathrm{H}_{2}$ (circles) and $\mathrm{OD}_{660}$ (plus sign).
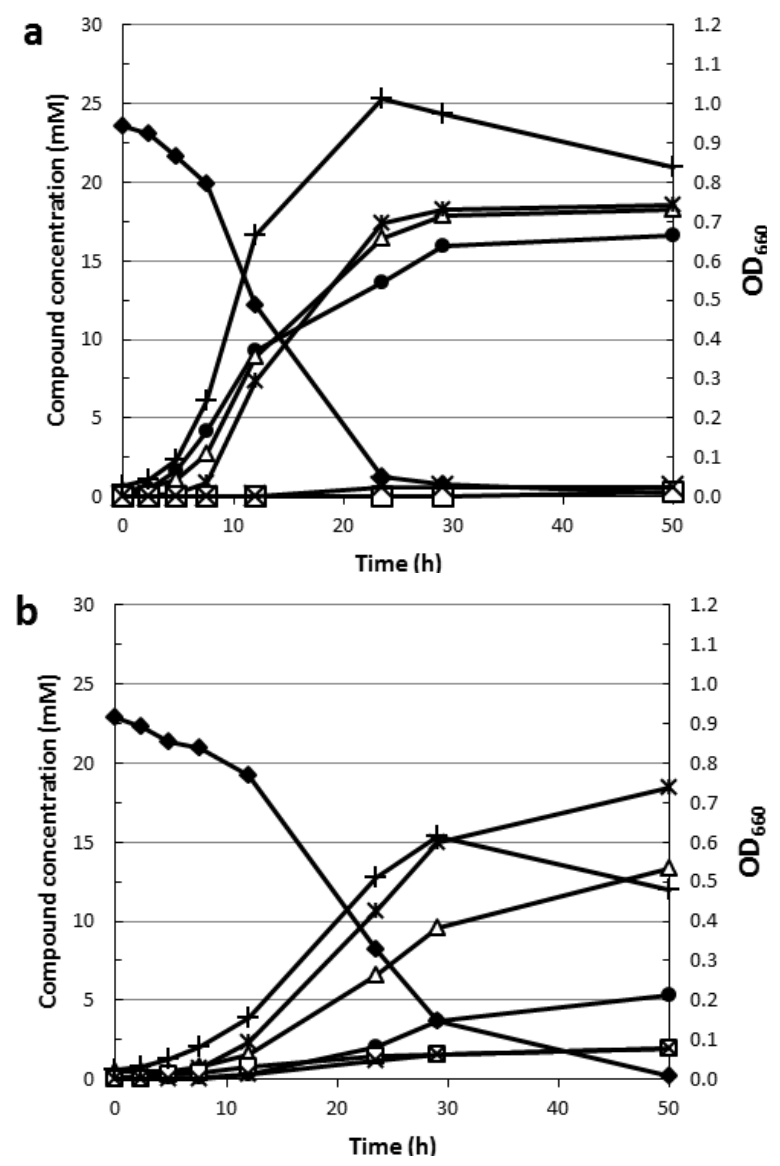
Figure 3. Schematic representation of two rhamnose associated gene clusters from $C$. saccharolyticus (Csac_0865-Csac_0876 and Csac_0989-Csac_0990). For each member of the cluster (grey arrows) the proposed function (text box) and locus tag number (four digit number) is given. Presented $\log 2$ values represent the ratio between transcription levels of the specific gene during growth on rhamnose with respect to growth on glucose; $(+)$ upregulated, (-) downregulated on rhamnose versus glucose [33].

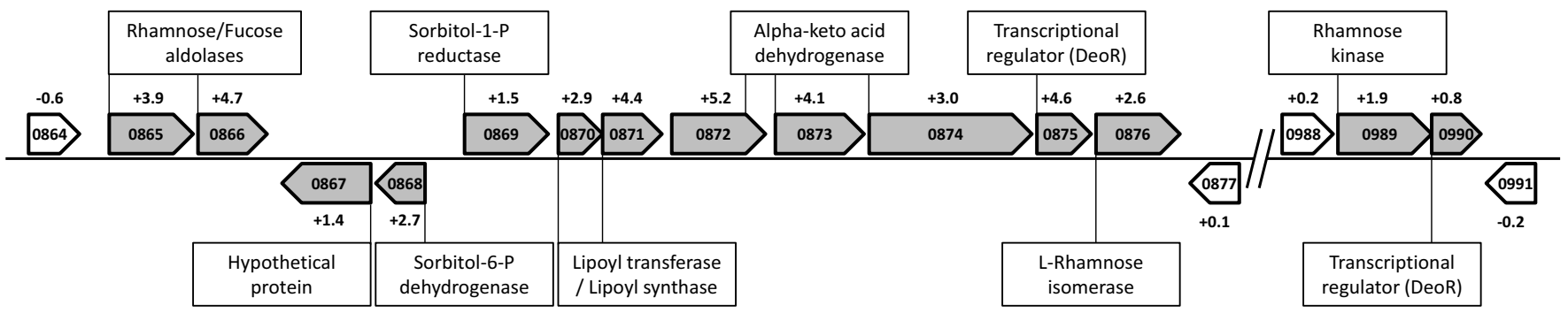

Table 1. Overview of Caldicellulosiruptor species which are able to grow on rhamnose. There is a correlation between the ability to grow on rhamnose and the presence of gene clusters orthologous to the rhamnose associated gene clusters identified in C. saccharolyticus (Figure 3). nt, not tested for growth on rhamnose. $(+)$, able to grow of rhamnose/gene cluster is present in genome. (-), no growth observed on rhamnose/gene cluster is not present in genome. ns, not sequenced.

\begin{tabular}{ccccc}
\hline Strain & $\begin{array}{c}\text { Growth on } \\
\text { Rhamnose }\end{array}$ & $\begin{array}{c}\text { Gene cluster } \\
\text { Csac_0865-76 }\end{array}$ & $\begin{array}{c}\text { Gene cluster } \\
\text { Csac_0989-90 }\end{array}$ & Reference \\
\hline C. saccharolyticus & + & + & + & {$[13]$} \\
C. bescii & + & + & + & {$[28]$} \\
C. owensensis & + & + & + & {$[21]$} \\
C. obsidiansis & $\mathrm{nt}$ & + & + & {$[20]$} \\
C. kronotskyensis & $\mathrm{nt}$ & + & + & {$[22]$} \\
C. hydrothermalis & $\mathrm{nt}$ & + & - & {$[22]$} \\
C. kristjanssonii & - & - & - & {$[17]$} \\
C. lactoaceticus & - & - & $\mathrm{ns}$ & {$[23]$} \\
C. acetigenus & $\mathrm{nt}$ & $\mathrm{ns}$ & &
\end{tabular}

\subsection{Involvement of Pyrophosphate in the Energy Metabolism}

From a bioenergetics point of view, glucose fermentation is optimal when acetate is the only end product, because an additional ATP is generated during the final acetate-forming step (Figure 1). When it is assumed that the ABC-transporter mediated substrate uptake requires 1 ATP, overall ATP yields become 1.5 ATP per acetate versus only 0.5 ATP per lactate or ethanol. However, ATP yields might even be higher when the involvement of pyrophosphate $\left(\mathrm{PP}_{\mathrm{i}}\right)$ as an energy carrier is considered.

$\mathrm{PP}_{\mathrm{i}}$ is a by-product of biosynthesis reactions like DNA and RNA synthesis or is generated when the amino acids are coupled to their tRNAs during protein synthesis [69]. Since these reactions are close to equilibrium accumulation of $\mathrm{PP}_{\mathrm{i}}$ is believed to have an inhibitory effect on growth, and only the effective removal of $\mathrm{PP}_{\mathrm{i}}$ drives these biosynthetic reactions forward [70]. When $\mathrm{PP}_{\mathrm{i}}$ is hydrolysed to $\mathrm{P}_{\mathrm{i}}$ by a cytosolic inorganic pyrophosphatase (PPase), the free energy just dissipates as heat. C. saccharolyticus 
does not contain a cytosolic PPase but possesses a membrane bound $\mathrm{H}^{+}$-translocating PPase [71], which allows the free energy released upon $\mathrm{PP}_{\mathrm{i}}$ hydrolysis to be preserved as a proton motive force. The high-energy phosphate bond of $\mathrm{PP}_{\mathrm{i}}$ can also be used for the phosphorylation of fructose 6-phosphate, catalyzed by a $\mathrm{PP}_{\mathrm{i}}$-dependent phosphofructokinase (Figure 1).

Furthermore, $\mathrm{PP}_{\mathrm{i}}$ is consumed during the catabolic conversion of phosphoenolpyruvate to pyruvate, catalyzed by pyruvate phosphate dikinase (PPDK). Such a catabolic role for PPDK was proposed based on the increase in transcript level of the $p p d k$ gene under increased glycolytic fluxes [33,71]. Altogether, the use of $\mathrm{PP}_{\mathrm{i}}$ as an energy donor could be a way for the organism to deal with the relative low ATP yields which are usually associated with fermentation [72].

\subsection{Mechanism Involved in Mixed Acid Fermentation}

$\mathrm{H}_{2}$ has been reported as a growth inhibitor for C. saccharolyticus [16,73] and a critical dissolved $\mathrm{H}_{2}$ concentration, which leads to the complete inhibition of growth, of $2.2 \mathrm{mmol} / \mathrm{L}$ has been determined for controlled batch cultivations [74]. In addition, an elevated $\mathrm{P}_{\mathrm{H} 2}$ has been shown to cause a switch in the fermentation profile, leading to increased formation of ethanol and lactate, in both controlled batch and chemostat cultivations $[12,60,74,75]$. Willquist et al. reported that in controlled batch fermentations the initiation of lactate formation coincided with an increment in both the internal $\mathrm{NADH} / \mathrm{NAD}{ }^{+}$ratio and the $\mathrm{P}_{\mathrm{H} 2}$ of the system $[57,75]$.

An increase of the overall carbon flux through glycolysis results in a higher NADH production rate. To maintain a constant $\mathrm{NADH} / \mathrm{NAD}^{+}$ratio a subsequently higher $\mathrm{H}_{2}$ formation rate is required. However, when the $\mathrm{H}_{2}$ formation rate (volumetric $\mathrm{H}_{2}$ production rate) exceeds the $\mathrm{H}_{2}$ liquid to gas mass transfer rate, $\mathrm{H}_{2}$ will accumulate in the liquid phase. In some cases this can even lead to super saturation of the liquid, meaning that the dissolved $\mathrm{H}_{2}$ concentration exceeds the maximal theoretical $\mathrm{H}_{2}$ solubility [74,76]. Such high dissolved $\mathrm{H}_{2}$ levels inhibit $\mathrm{H}_{2}$ formation and presumably cause an increase in the $\mathrm{NADH} / \mathrm{NAD}^{+}$ratio. An increased $\mathrm{NADH} / \mathrm{NAD}^{+}$ratio has been shown to have an inhibitory effect on GAPDH activity thus limiting the glycolytic flux [75] and consequently leads to a decrease in substrate consumption and growth rate. A switch to lactate formation alleviates the inhibitory effect of an increased $\mathrm{NADH} / \mathrm{NAD}^{+}$ratio by causing a decrease of the $\mathrm{NADH} / \mathrm{NAD}{ }^{+}$ratio through the reduction of pyruvate.

A clear switch to lactate formation caused by an increase in glycolytic flux can be observed for C. saccharolyticus grown in a chemostat under high $\mathrm{P}_{\mathrm{H} 2}$ ([77], Figure 4a). When the glucose load is increased from $20 \mathrm{mM}$ to $40 \mathrm{mM}$, end-product formation is switched from mainly acetate to mainly lactate, respectively. After the switch to $40 \mathrm{mM}$ glucose some adaptation time is required before a new steady state is achieved. During this adaptation period substantially higher amounts of glucose were detected in the culture effluent, probably indicating an inhibition of the glycolytic flux at the level of GAPDH. When a new steady state was achieved, residual glucose was only slightly higher with respect to the $20 \mathrm{mM}$ condition. As a consequence of the increase in glycolytic flux, the lactate concentration dramatically increased while the acetate concentration hardly changed, indicating that during both substrate loads a similar volumetric $\mathrm{H}_{2}$ productivity was maintained. These data indicate that under these conditions the organism is not capable of dealing with the increased glycolytic flux by increasing its $\mathrm{H}_{2}$ productivity, but requires a switch to lactate formation. Although oxaloacetate 
formation was discernible under a $20 \mathrm{mM}$ glucose load, significantly higher and therefore quantifiable levels of oxaloacetate were detected under the $40 \mathrm{mM}$ glucose load condition. This observation together with the increased flux towards lactate suggests that in the newly achieved steady state, a bottleneck exists at the level of pyruvate.

Ethanol formation can also serve as reductant sink in C. saccharolyticus. For some chemostat cultivation conditions a decrease in $\mathrm{H}_{2}$ yield is only associated with ethanol formation and not with lactate formation $[56,60,75]$. These conditions concern low substrate loads, and the observed increase in ethanol formation was triggered by an increase of the dilution rate $[56,75]$ or a change in mode of gas flushing [60], both potentially generating a moderate increase in the $\mathrm{H}_{2}$ level of the system.

Figure 4. Fermentation profile of $C$. saccharolyticus (a) grown in a chemostat under high $\mathrm{H}_{2}$ partial pressure at two different glucose concentrations (see Section 4.4), (b) grown in a chemostat without $\mathrm{NH}_{4}{ }^{+}$in the medium under low and high $\mathrm{H}_{2}$ partial pressure (see Section 6.4). The switch from $20 \mathrm{mM}$ to $40 \mathrm{mM}$ glucose containing-medium and the switch from low to high $\mathrm{H}_{2}$ partial pressure cultivation condition is indicated by a vertical line. Acetate (open triangles), lactate (open squares), ethanol (crosses), $\mathrm{CO}_{2}$ (open circles), oxaloacetate (asterisks), glucose out (open diamonds) and CDW (plus sign). Chemostat cultivation parameters ( $3 \mathrm{~L}$ reactor, $1 \mathrm{~L}$ working volume, $\mathrm{pH}=7.0(\mathrm{NaOH})$, temp $70{ }^{\circ} \mathrm{C}, \mathrm{D}=0.1 \mathrm{~h}^{-1}$, low $\mathrm{P}_{\mathrm{H} 2}$ [sparging $(4 \mathrm{~L} / \mathrm{h})$ with $\mathrm{N}_{2}$ gas and stirring speed $\left.\left.=250 \mathrm{rpm}\right]\right)$, high $\mathrm{P}_{\mathrm{H} 2}$ [headspace flushing ( $4 \mathrm{~L} / \mathrm{h})$ with $\mathrm{H}_{2}$ gas and stirring speed $\left.\left.=50 \mathrm{rpm}\right]\right)$.
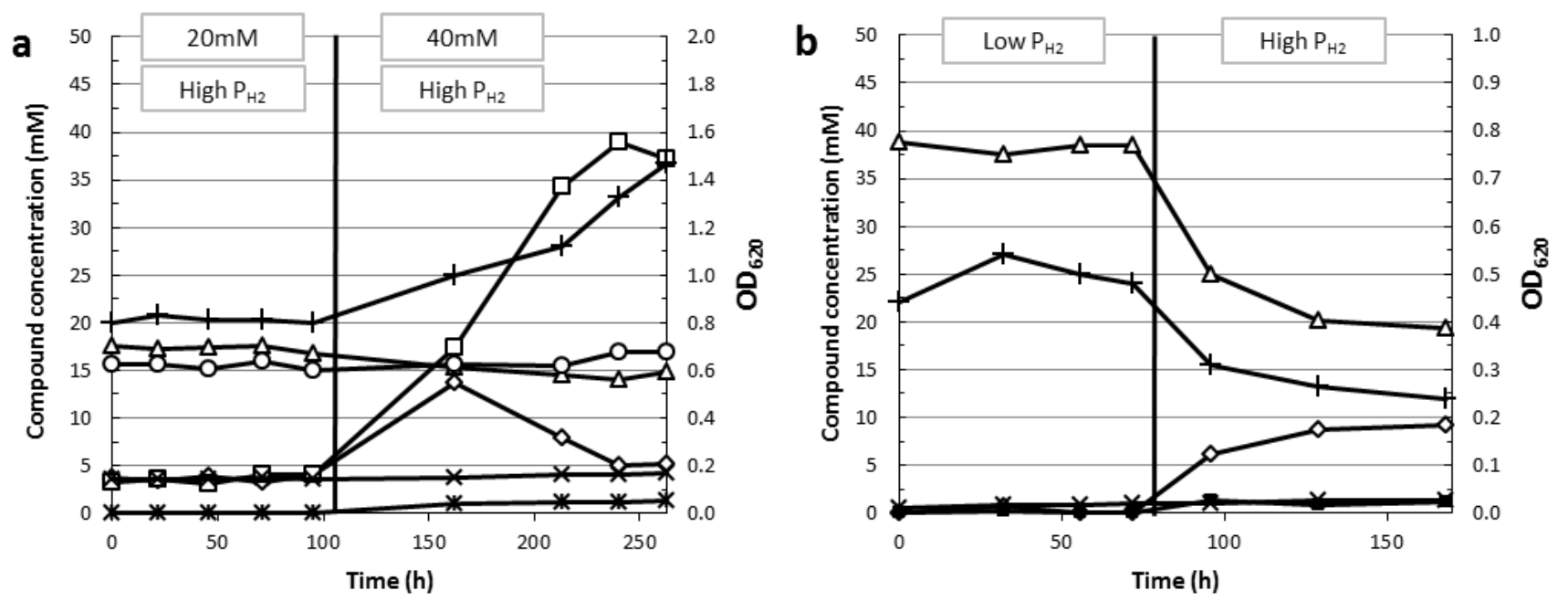

\subsection{Regulation of Reductant Disposal Pathways}

Hydrogen, ethanol and lactate formation are the main routes for reductant disposal in $C$. saccharolyticus. The gene expression of the hydrogenases and both alcohol dehydrogenases involved in ethanol formation are proposed to be under the control of the NADH/NAD ${ }^{+}$sensitive transcriptional regulator Rex [60] (Figure 5). Cultivation of C. saccharolyticus under high $\mathrm{P}_{\mathrm{H} 2}$ conditions was shown to lead to an upregulation of both the hydrogenases and alcohol dehydrogenases [60]. In addition, the $l d h$ transcript level is also upregulated under high $\mathrm{P}_{\mathrm{H} 2}$ conditions, but in silico analysis of the ldh promoter region did not reveal a likely Rex operator binding sequence [60]. Thus, the exact regulatory mechanism triggering $l d h$ transcription remains therefore unclear. Nonetheless, lactate dehydrogenase 
activity has been shown to be regulated at the enzyme level, with fructose 1,6-bisphosphate and ATP acting as allosteric activators and both $\mathrm{NAD}^{+}$and $\mathrm{PP}_{\mathrm{i}}$ as competitive inhibitors [57]. Under high $\mathrm{P}_{\mathrm{H} 2}$ cultivation conditions, enzyme activity assays revealed increased LDH activity with respect to low $\mathrm{P}_{\mathrm{H} 2}$ conditions $[57,75]$. A hampered glycolytic flux at the level of GAPDH, potentially triggered by NADH build-up, might lead to the accumulation of fructose 1,6-bisphosphate. In turn, the accumulated level of fructose 1,6-bisphosphate could stimulate lactate formation (Figure 5), explaining the switch to lactate under high $\mathrm{P}_{\mathrm{H} 2}$ at the enzyme level.

Figure 5. Overview of the regulatory mechanisms involved in the central metabolism of Caldicellulosiruptor saccharolyticus. The abbreviations of the compounds and reactions (circled numbers) are given in the legend of Figure 1. For the enzyme reactions given in green (circled numbers, green) the encoding genes are upregulated under increased $\mathrm{P}_{\mathrm{H} 2}$ [60]. Those which are under the control of the REX transcriptional regulator are marked with a green dot. $\mathrm{H}_{2}$ inhibits its own formation $(\mathbf{R 4 5}, \mathbf{R 4 6})$ and accumulation of NADH inhibits glyceraldehyde-3-phosphate dehydrogenase $(\mathbf{R 2 6})$. $\mathrm{PP}_{\mathrm{i}}$, a by-product of biosynthesis, acts as an inhibitor of both pyruvate kinase (R30) and lactate dehydrogenase (R35) activity. Both ATP and F-1,6-bP are activators of lactate dehydrogenase (R35) activity.

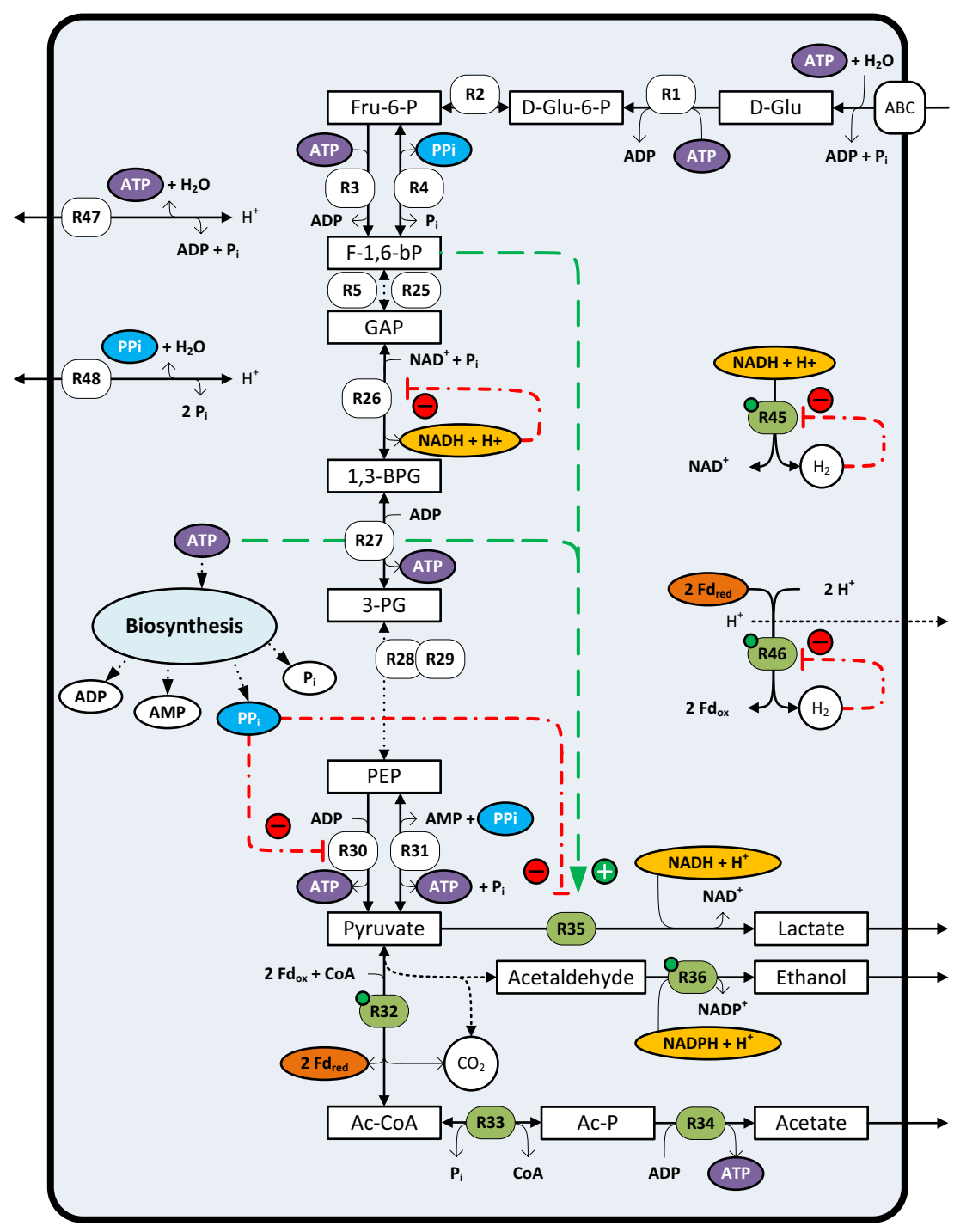


Interestingly, LDH enzyme activity can also be measured under non-lactate producing conditions, which suggest that additional factors control lactate formation [57,75]. Low levels of lactate formation can be observed at the end of growth during the transition to stationary phase for cultures grown in controlled batch systems [55,57,75,78,79]. This initiation of the lactate formation coincided with a relative increase in ATP levels and a relative decrease in $\mathrm{PP}_{\mathrm{i}}$ levels [57,71]. These observed changes in ATP and $\mathrm{PP}_{\mathrm{i}}$ levels could release the inhibitory effect of $\mathrm{PP}_{\mathrm{i}}$ and stimulate LDH activity [57] (Figure 5). For this latter mode of LDH activity regulation, the lactate formation is proposed to be coupled to the energy metabolism. Accordingly, lactate formation is prevented during exponential growth, which is associated with a high anabolic activity and high $\mathrm{PP}_{\mathrm{i}}$ levels. Whereas, during the transition to stationary phase, which is associated with low anabolic activity and relative low $\mathrm{PP}_{\mathrm{i}}$ levels, lactate formation inhibition is alleviated [12,57].

\section{Thermodynamic Considerations of Glucose Conversion and $\mathbf{H}_{2}$ Formation}

For $C$. saccharolyticus an elevated hydrogen concentration has been shown to affect fermentation performance, leading to a mixed acid fermentation [60,73-75]. These observed changes in the fermentation profile as a function of the $\mathrm{H}_{2}$ concentration can be conceptually explained by considering the thermodynamics of the reactions leading to $\mathrm{H}_{2}$ formation $[9,10]$. The Gibbs energy $\left(\Delta \mathrm{G}^{\prime}\right)$ for a specific reaction can be calculated from the standard Gibbs energy $\left(\Delta \mathrm{G}^{01}\right)$ and the reactant concentrations by the following relation:

$$
\Delta \mathrm{G}^{\prime}=\Delta \mathrm{G}^{0 \prime}+\mathrm{RT} \ln \left([\mathrm{C}]^{\mathrm{c}}[\mathrm{D}]^{\mathrm{d}} /[\mathrm{A}]^{\mathrm{a}}[\mathrm{B}]^{\mathrm{b}}\right)
$$

where $\Delta \mathrm{G}^{0_{1}}$ is the standard Gibbs energy $(\mathrm{J} / \mathrm{mol}, 1 \mathrm{~mol}$ concentration of all reactants, at a neutral $\mathrm{pH}$ and at a specific temperature), $\mathrm{R}$ is the gas constant $\left(\mathrm{J} / \mathrm{mol}^{*} \mathrm{~K}\right)$; $\mathrm{T}$ is the temperature $(\mathrm{K}), \mathrm{A}$ and $\mathrm{B}$ are the substrate concentrations with respective stoichiometric reaction coefficients $\mathrm{a}, \mathrm{b}$; and $\mathrm{C}$ and $\mathrm{D}$ are the reaction products with respective stoichiometric reaction coefficients $\mathrm{c}, \mathrm{d}$.

When $\mathrm{H}_{2}$ formation occurs in the aqueous phase $\mathrm{H}_{2}$ supersaturation can occur. For instance, over-saturation of 12 to 34 times the equilibrium concentration has been reported for $C$. saccharolyticus cultivations [74]. This indicates that estimating the dissolved $\mathrm{H}_{2}$ concentration from the measured $\mathrm{H}_{2}$ partial pressure by using the equilibrium constant does not always give an accurate representation of the state of the system. So $\mathrm{H}_{2}(\mathrm{aq})$, instead of the $\mathrm{H}_{2}$ partial pressure $\left(\mathrm{P}_{\mathrm{H} 2}\right)$, should be used as a parameter when investigating the effect of $\mathrm{H}_{2}$ on the metabolism. Therefore, all Gibbs energy calculations discussed herein were performed using the $\Delta_{\mathrm{f}} \mathrm{G}^{0}$ of the dissolved $\mathrm{H}_{2}$ concentration $\left(\mathrm{H}_{2}(\mathrm{aq})\right.$ ).

Under standard conditions $\left(25^{\circ} \mathrm{C}\right.$ ), acetate formation (Equation $1, \Delta \mathrm{G}^{0,}=-142.6 \mathrm{~kJ} /$ reaction) is energetically less favorable then lactate (Equation 3, $\Delta \mathrm{G}^{0_{\mathrm{r}}}=-195.0 \mathrm{~kJ} /$ reaction) and ethanol (Equation 2, $\Delta \mathrm{G}^{0^{\prime}}=-231.8 \mathrm{~kJ} /$ reaction) formation. The Gibbs energy $\left(\Delta \mathrm{G}^{\prime}\right)$ for the complete conversion of glucose to acetate depends, however, on the $\mathrm{H}_{2}$ concentration (Equation 1), whereas the $\Delta \mathrm{G}^{\prime}$ for both ethanol and lactate formation from glucose is independent of the $\mathrm{H}_{2}$ concentration (Equations 2 and 3, respectively). This means that the complete oxidation of glucose to acetate becomes energetically more favorable when the dissolved $\mathrm{H}_{2}$ concentration is lowered. For example, acetate formation becomes energetically favorable compared to lactate or ethanol formation when the dissolved $\mathrm{H}_{2}$ concentration drops below 5.0 or $0.12 \mathrm{mM}$, respectively (Figure 6a, supplementary data $\mathrm{S} 1$ ). 
Figure 6. Effect of the $\mathrm{H}_{2}$ concentration on the Gibbs energy change of reactions involved in $\mathrm{H}_{2}$ formation: (a) $\Delta \mathrm{G}^{\prime}$ of the complete oxidation of $1 \mathrm{~mol}$ of glucose to acetate (closed diamonds), lactate (open squares) and ethanol (closed circles) at $25{ }^{\circ} \mathrm{C}$ (solid lines) and $70{ }^{\circ} \mathrm{C}$ (dashed lines); (b) $\Delta \mathrm{G}^{\prime}$ of $\mathrm{H}_{2}$ formation from $\mathrm{NADH}$ (dotted line), reduced ferredoxin (dashed line) and via the bifurcating system (50\% NADH and $50 \% \mathrm{Fd}_{\text {red }}$ ) (solid line) at $25^{\circ} \mathrm{C}$ and $70{ }^{\circ} \mathrm{C}$. Values were calculated from data presented in ([80-84]).
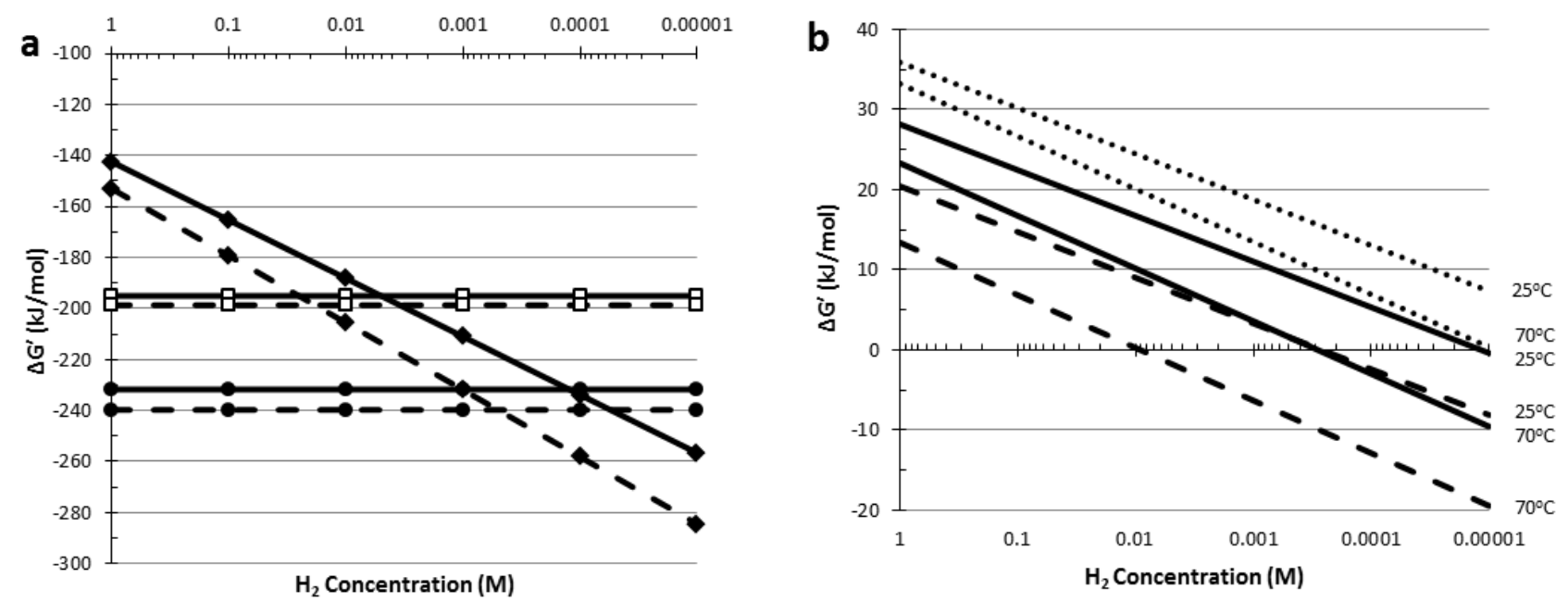

However, considering the Gibbs energies of the overall conversions can be misleading, as the thermodynamics of the involved partial reactions can be less favorable. Acetate formation is inevitably linked to $\mathrm{H}_{2}$ formation and the $\Delta \mathrm{G}^{0}$ of the redox reaction coupling the reoxidation of the reduced electron carriers $\mathrm{NADH}$ or $\mathrm{Fd}_{\text {red }}$ to proton reduction are endergonic under standard conditions (Figure $6 \mathrm{~b}$, supplementary data $\mathrm{S} 2$ ). Decreasing the dissolved $\mathrm{H}_{2}$ concentration will lower the $\Delta \mathrm{G}^{\prime}$ of these $\mathrm{H}_{2}$ forming reactions, but an extremely low $\mathrm{H}_{2}$ concentration is required before $\mathrm{H}_{2}$ formation from NADH becomes exergonic $(0.5 \mu \mathrm{M})\left(\mathrm{Fd}_{\text {red }}, 0.2 \mathrm{mM}\right)$ (Figure $\left.6 \mathrm{~b}\right)$. Therefore, at elevated $\mathrm{H}_{2}$ concentrations this partial reaction raises a thermodynamic barrier. $\mathrm{NADH}$ dependent pyruvate reduction to lactate, on the other hand, has a negative Gibbs energy $\left(\Delta \mathrm{G}^{0{ }^{\prime}}=-25.0 \mathrm{~kJ} / \mathrm{reaction}\right)$ and is independent of the dissolved $\mathrm{H}_{2}$ concentration. This means that under certain conditions lactate formation is more feasible, despite the more negative $\Delta \mathrm{G}^{\prime}$ for acetate formation compared to lactate formation (Equations 1 and 3), simply because $\mathrm{H}_{2}$ formation from NADH is energetically unfavorable.

As explained, the thermodynamic barrier associated with $\mathrm{H}_{2}$ formation from NADH can be lowered by decreasing the dissolved $\mathrm{H}_{2}$ concentrations, moreover this barrier may also be tackled by an additional input of energy. The latter can be achieved by reverse electron transport catalyzed by an $\mathrm{NADH}$ : ferredoxin oxidoreductase, where the transfer of electrons from NADH to $\mathrm{Fd}_{\text {red }}$ is coupled to a proton or ion gradient [85]. Produced $\mathrm{Fd}_{\text {red }}$ can subsequently be used for $\mathrm{H}_{2}$ formation. Alternatively, the energetically more favourable oxidation of $\mathrm{Fd}_{\text {red }}$ can be used to push the less favourable formation of $\mathrm{H}_{2}$ from NADH in a bifurcating system (Figure $6 \mathrm{~b}$ ). Such a bifurcating function has been identified for T. maritima and was, based on protein sequences, also attributed to the Fe-only hydrogenase (hyd) of C. saccharolyticus [86]. However, the gene-arrangement of the Fe-only hydrogenase (hyd) in C. saccharolyticus is identical to that of Thermoanaerobacter tengcongensis [33], for which a 
NADH-dependent hydrogenase activity has been demonstrated [64], thus arguing against a bifurcating systems in C. saccharolyticus.

In general, $\mathrm{H}_{2}$ formation is thermodynamically more favorable at elevated temperatures because (i) $\Delta \mathrm{G}^{0_{1}}$ values of the involved reactions are lower at increased temperature, and (ii) the RT coefficient in Equation 4 is temperature dependent, thus enhancing the effect of a decreased $\mathrm{H}_{2}$ concentration (Figure 6a,b). Overall, thermophilic organisms have been shown to be able to produce $\mathrm{H}_{2}$ at higher yields compared to mesophilic organisms. For thermophiles yields approaching the theoretical limit of $4 \mathrm{H}_{2}$ per hexose [83] have been reported, while for mesophiles $\mathrm{H}_{2}$ yields generally do not exceed $2 \mathrm{H}_{2}$ per hexose $[9,11,12]$. These higher yields reflect the indicated thermodynamic advantage but also the lower diversity of fermentation end products observed for those thermophiles. For a specific organism the diversity of available electron acceptors, and formed end products, depends on the metabolic capabilities of the organism. Whether a specific pathway is operational depends on the regulation of that pathway at the transcription or translation level, but also depends on the kinetic properties and regulation of the enzyme activities of the specific enzymatic steps of that pathway.

\section{Factors Limiting $\mathrm{H}_{2}$ Formation}

With an eye to the potential use of complex biomass for $\mathrm{H}_{2}$ production a multitude of fermentability studies have been performed using C. saccharolyticus. An overview of the literature related to fermentability studies on either crop-based feedstock or industrial waste stream derived biomass is given in Table 2. Those investigations mainly focus on the fermentability of various complex substrates, associated $\mathrm{H}_{2}$ formation and the effect of pretreatment on substrate accessibility and growth, overall demonstrating the bacterium's broad hydrolytic capacity.

Table 2. Literature overview of fermentability studies on $C$. saccharolyticus using crop-based feedstock or industrial waste stream derived biomass. * Extraction methods and mechanical pre-treatments were excluded in this overview, biological pre-treatment indicated pre-treatment by pre-incubation with Bacillus amyloliquefaciens; ** Multiple, different pre-treatments used; $\mathrm{B}$, batch cultivation; $\mathrm{CB}$, controlled batch cultivation; ${ }^{\$}$ Minimal and maximal reported $\mathrm{H}_{2}$ yields are given.

\begin{tabular}{ccccc}
\hline Reference & Substrate & Pre-treatment * & Cultivation method & H $_{2}$ yields '/Remarks \\
\hline$[87]$ & Wheat grains & Enzymatic & $\mathrm{B}$ & \\
& Wheat straw & Acid/Enzymatic & $\mathrm{B}$ & \\
{$[88]$} & Barley straw & Acid/Enzymatic ** & $\mathrm{B}$ & Proteome data \\
{$[29]$} & Crystalline cellulose & - & $\mathrm{B}$ & \\
& Birchwood xylan & - & $\mathrm{B}$ & \\
& Switchgrass & Acid & $\mathrm{B}$ & \\
& Whatman no. 1 filterpaper & - & $\mathrm{B}$ & \\
{$[89]$} & Wheat straw & Acid/Enzymatic & $\mathrm{B}$ & \\
& Barley straw & Acid/Enzymatic & $\mathrm{B}$ & \\
& Corn stalk & Acid/Enzymatic & $\mathrm{B}$ & Microarray data \\
{$[36]$} & Corn cob & Acid/Enzymatic & $\mathrm{B}$ & Microarray data \\
& Poplar & - & $\mathrm{B}$ & $0.9-4.2$ \\
\hline 90$]$ & Switchgrass & Acid & B & \\
\hline
\end{tabular}


Table 2. Cont.

\begin{tabular}{|c|c|c|c|c|}
\hline Reference & Substrate & Pre-treatment * & Cultivation method & $\mathrm{H}_{2}$ yields ${ }^{\$} /$ Remarks \\
\hline \multirow{2}{*}[91]{} & Potato steam peels & Enzymatic & $\mathrm{CB}$ & $1.7-3.4$ \\
\hline & Potato steam peels & - & $\mathrm{CB}$ & $1.1-3.5$ \\
\hline \multirow[t]{6}{*}[92]{} & Filter paper & - & $\mathrm{B}$ & \\
\hline & Wheat straw & Biological & B & \\
\hline & Silphium perfoliatum leaves & Biological & B & \\
\hline & Maize leaves & Biological & B & \\
\hline & Sugar cane bagasse & Biological & B & \\
\hline & Sweet sorghum whole plant & Biological & B & \\
\hline [93] & Sugar beet & - & $\mathrm{CB}$ & 3.0 \\
\hline [94] & Sweet sorghum bagasse & Alkaline/Enzymatic ** & $\mathrm{B} / \mathrm{CB}$ & $1.3-2.6$ \\
\hline \multirow[t]{2}{*}{ [55] } & Carrot pulp & Enzymatic & $\mathrm{CB}$ & $1.3-2.8$ \\
\hline & Carrot pulp & - & $\mathrm{CB}$ & \\
\hline \multirow[t]{2}{*}[35]{} & Crystalline cellulose & - & $\mathrm{B}$ & Proteome data \\
\hline & Cellobiose & - & B & Microarray data \\
\hline \multirow[t]{2}{*}{ [95] } & Switchgrass & - & B & \\
\hline & Poplar & - & B & \\
\hline \multirow[t]{3}{*}{ [53] } & Xylan & - & B & Microarray data \\
\hline & Xyloglucan & - & B & Microarray data \\
\hline & Xyloglucan-oligosaccharides & - & B & Microarray data \\
\hline \multirow[t]{5}{*}{ [96] } & Barley straw & Acid/Enzymatic & B & \\
\hline & Corn stalk & Acid/Enzymatic & B & \\
\hline & Barley grain & Enzymatic & B & \\
\hline & Corn grain & Enzymatic & B & \\
\hline & Sugar beet & - & B & \\
\hline \multirow[t]{7}{*}{ [97] } & Sweet sorghum plant & - & B & \\
\hline & Sweet sorghum juice & - & B & \\
\hline & Dry sugarcane bagasse & - & B & \\
\hline & Wheat straw & - & B & \\
\hline & Maize leaves & - & B & \\
\hline & Maize leaves & Biological & B & \\
\hline & Silphium trifoliatum leaves & - & B & \\
\hline [54] & Miscanthus giganteus & Alkaline/Enzymatic & $\mathrm{B} / \mathrm{CB}$ & $2.4-3.4$ \\
\hline \multirow[t]{3}{*}[52]{} & Agarose & - & B & \\
\hline & Alginic acid & - & B & $\begin{array}{l}\text { matrixes } \\
\text { mation }\end{array}$ \\
\hline & Pine wood shavings & - & B & \\
\hline \multirow[t]{3}{*}{ [98] } & Jerusalem artichoke & - & $\mathrm{B}$ & Co-fermentation with \\
\hline & Fresh waste water sludge & - & B & natural biogas- \\
\hline & Pig manure slurry & - & B & producing consortia \\
\hline [78] & Paper sludge & Acid/Enzymatic & $\mathrm{CB}$ & \\
\hline [99] & Paper sludge & Acid/Enzymatic & B & \\
\hline
\end{tabular}

On the other hand, growth experiments on pure sugar substrates can be used to investigate the specific response associated with a certain substrate or to examine specific pathways involved in the metabolism of a substrate. Table 3 gives an overview of the literature related to growth experiments on pure sugars and pure sugar mixes, including the determined $\mathrm{H}_{2}$ yields and $\mathrm{H}_{2}$ productivities. The currently available fermentation data are discussed here to highlight the different factors limiting $\mathrm{H}_{2}$ formation during the fermentative $\mathrm{H}_{2}$ production by $C$. saccharolyticus. 
Table 3. Literature overview of fermentation studies on $C$. saccharolyticus grown on pure sugar substrates. ${ }^{*}$ Yields in mol $\mathrm{H}_{2} / \mathrm{mol}$ hexose; nd, not determined; ** For batch cultivations the maximal productivity is given; nd, not determined; $\mathrm{B}$, batch cultivation; and $\mathrm{CB}$, controlled batch cultivation; Chem, chemostat cultivations.

\begin{tabular}{|c|c|c|c|c|c|c|c|}
\hline Reference & Substrate & $\begin{array}{l}\text { Substrate } \\
\text { load }(g / L)\end{array}$ & $\mathrm{H}_{2}$ Yield * & $\begin{array}{c}\text { Productivity ** } \\
(\text { mmol/(L*h)) }\end{array}$ & $\begin{array}{c}\text { Cultivation } \\
\text { method }\end{array}$ & $\begin{array}{c}\text { Dilution } \\
\text { rate }\left(h^{-1}\right) \\
\end{array}$ & Remarks \\
\hline \multirow{2}{*}[100]{} & & 10 & 3.4 & $23.6 \mathrm{~mol} /(\mathrm{g} * \mathrm{~h})$ & $\mathrm{CB}$ & & No YE in medium \\
\hline & & 4 & 3.5 & $10.4 \mathrm{~mol} /(\mathrm{g} * \mathrm{~h})$ & Chem & 0.05 & No YE in medium \\
\hline \multirow[t]{2}{*}[75]{} & Glucose & 5 & 3.5 & 5.2 & Chem & 0.05 & \\
\hline & & 5 & 2.9 & 11.0 & Chem & 0.15 & Residual glucose (3 mM) \\
\hline [101] & Glucose & 5 & nd & nd & B & & Extracellular proteome \\
\hline \multirow[t]{2}{*}[91]{} & Glucose & 10 & 3.4 & 12.0 & $\mathrm{CB}$ & & \\
\hline & & 31 & 2.8 & 12.9 & $\mathrm{CB}$ & & Residual glucose \\
\hline [93] & Sucrose & 10 & 2.9 & 7.1 & $\mathrm{CB}$ & & \\
\hline \multirow[t]{2}{*}{ [94] } & Glucose/Xylose/Sucrose & 10 & 3.2 & 10.7 & $\mathrm{CB}$ & & Sugar mix \\
\hline & $(6: 2.5: 1.5, \mathrm{w} / \mathrm{w} / \mathrm{w})$ & 20 & 2.8 & 9.4 & $\mathrm{CB}$ & & Sugar mix \\
\hline [55] & $(7: 3, w / w)$ & 20 & 2.6 & 12.2 & $\mathrm{CB}$ & & Sugar mix \\
\hline \multirow[t]{2}{*}[35]{} & Xylose & 5 & nd & nd & $\mathrm{B}$ & & Proteome data \\
\hline & Glucose & 5 & nd & nd & B & & Proteome data \\
\hline$[50]$ & Glucose & 5 & nd & nd & $\mathrm{B}$ & & Extracellular proteome \\
\hline \multirow[t]{4}{*}{ [79] } & Sucrose & 4 & 2.7 & 23.0 & $\mathrm{CB}$ & & \\
\hline & & 4 & 3.1 & 11.8 & $\mathrm{CB}$ & & $\mathrm{CO}_{2}$ sparging \\
\hline & Glucose & 4 & 3.0 & 20.0 & $\mathrm{CB}$ & & \\
\hline & & 4 & 2.7 & 12.0 & $\mathrm{CB}$ & & $\mathrm{CO}_{2}$ sparging \\
\hline
\end{tabular}


Table 3. Cont

\begin{tabular}{|c|c|c|c|c|c|c|c|}
\hline Reference & Substrate & $\begin{array}{l}\text { Substrate } \\
\text { load (g/L) }\end{array}$ & $\mathrm{H}_{2}$ Yield * & $\begin{array}{c}\text { Productivity ** } \\
\left(\mathrm{mmol} /\left(L^{*} \mathrm{~h}\right)\right)\end{array}$ & $\begin{array}{c}\text { Cultivation } \\
\text { method }\end{array}$ & $\begin{array}{l}\text { Dilution } \\
\text { rate }\left(h^{-1}\right)\end{array}$ & Remarks \\
\hline \multirow{4}{*}{ [53] } & Mannose & 0.5 & nd & nd & $\mathrm{B}$ & & Microarray data \\
\hline & Xylose & 0.5 & nd & nd & $\mathrm{B}$ & & Microarray data \\
\hline & Fructose & 0.5 & nd & nd & B & & Microarray data \\
\hline & Galactose & 0.5 & nd & nd & B & & Microarray data \\
\hline \multirow{2}{*}[54]{} & $(7: 3 \mathrm{w} / \mathrm{w})$ & 14 & 3.3 & 10.1 & $\mathrm{CB}$ & & Sugar mix \\
\hline & & 28 & 2.4 & 9.7 & $\mathrm{CB}$ & & Sugar mix \\
\hline$[102]$ & Sucrose & 10.3 & 2.8 & 22.0 & Trickle bed & $0.2-0.3$ & $400 \mathrm{~L}$, non-axenic fermentation \\
\hline \multirow[t]{3}{*}[33]{} & Glucose & 4 & nd & nd & $\mathrm{CB}$ & & Microarray data \\
\hline & Xylose & 4 & nd & nd & $\mathrm{CB}$ & & Microarray data \\
\hline & Rhamnose & 4 & nd & nd & $\mathrm{CB}$ & & Microarray data \\
\hline \multirow{6}{*}[56]{} & & 4.4 & 3.1 & 11.0 & Chem & 0.30 & Residual glucose (12.4 mM) \\
\hline & & 4.4 & 3.0 & 12.4 & Chem & 0.35 & Residual glucose (12.7 mM) \\
\hline & & 1.9 & 4.0 & 4.0 & Chem & 0.09 & \\
\hline & & 1.9 & 3.3 & 9.9 & Chem & 0.30 & Residual glucose (0.6 mM) \\
\hline & & 4.1 & 3.5 & 7.7 & Chem & 0.09 & \\
\hline & & 4.1 & 3.1 & 11.6 & Chem & 0.30 & Residual glucose (11.9 mM) \\
\hline \multirow[t]{3}{*}[78]{} & Glucose & 10 & 2.5 & 10.7 & $\mathrm{CB}$ & & \\
\hline & Xylose & 10 & 2.7 & 11.3 & $\mathrm{CB}$ & & \\
\hline & Glucose/Xylose (11:3, w/w) & 8.4 & 2.4 & 9.2 & $\mathrm{CB}$ & & Sugar mix \\
\hline$[103]$ & Sucrose & 10 & 3.3 & 8.4 & $\mathrm{CB}$ & & \\
\hline
\end{tabular}




\subsection{Comparison between Hydrolysates and Pure Sugar Mixtures}

Studies on biomass hydrolysates and mono-saccharide mixtures, mimicking the biomass hydrolysates, showed that, while at low substrate loads fermentation performances were comparable, at higher substrate loads $\mathrm{H}_{2}$ yields were higher on the mixed mono-saccharides compared to the biomass hydrolysates. The difference in yields was caused by a shift to lactate formation during the growth on high substrate load hydrolysates. Interestingly, for the higher substrate concentrations, the total sugar consumption was higher during growth on hydrolysates compared to growth on sugar mixtures [55,91]. For C. saccharolyticus, grown on carrot pulp hydrolysate $(20 \mathrm{~g} / \mathrm{L})$, a lower cumulative $\mathrm{H}_{2}$ production was found, compared to growth on a glucose/fructose mixture $(20 \mathrm{~g} / \mathrm{L})$, while a relatively higher maximal $\mathrm{H}_{2}$ productivity was observed for the hydrolysate compared to the sugar mixture. During the growth on carrot pulp hydrolysates the relative higher $\mathrm{H}_{2}$ productivity preceded the switch to lactate formation [55]. These results demonstrate the relation between high $\mathrm{H}_{2}$ productivity, lactate formation and an overall low $\mathrm{H}_{2}$ yield. However, these described phenomena were not observed for fermentations on Miscanthus hydrolysates. For each tested substrate load (10, 14 and $28 \mathrm{~g} / \mathrm{L})$ fermentation performance during growth on the Miscanthus hydrolysate was similar to the glucose/xylose sugar mix and only moderate levels of lactate were formed even at high substrate loads [54]. The differences in $\mathrm{H}_{2}$ production characteristics between the discussed hydrolysates might be related to the difference in sugar composition of the hydrolysates or the differences in pretreatment applied prior to hydrolysis.

In general, biomass derived hydrolysates might contain substances which negatively affect growth or fermentation performance. For example, the dilute-acid pretreatment of lignocellulosic biomass releases undesirable inhibiting compounds like 5-hydroxymethylfurural (HMF), furfural, phenolic compounds and acetate [89] and a growth inhibition of 50\% was reported for C. saccharolyticus in the presence of 1-2 g/L HMF or furfural [54].

\subsection{Incomplete Substrate Conversion}

For chemostat cultivation on glucose ( 4.4 and $5 \mathrm{~g} / \mathrm{L})$ it was shown that a dilution rate (D) exceeding $0.1 \mathrm{~h}^{-1}$ gave rise to an incomplete substrate conversion but also to a lower $\mathrm{H}_{2}$ yield. The concomitant decrease in both biomass level and $\mathrm{H}_{2}$ yield caused the volumetric $\mathrm{H}_{2}$ productivity $\left(\mathrm{mmol} / \mathrm{L}^{*} \mathrm{~h}\right)$ to level off at higher dilution rates [56,75]. The observed lower $\mathrm{H}_{2}$ yield reflects the shift in end product formation, from mainly acetate at a low dilution rate of $0.05 \mathrm{~h}^{-1}$ to a mix of acetate and ethanol at a $\mathrm{D}=0.15 \mathrm{~h}^{-1}$ [75]. Interestingly, no lactate was produced during these chemostat cultivations [56,75]. The observed incomplete substrate conversion indicated that another factor was limiting under those conditions. Indeed, increasing the yeast extract to glucose ratio, from 0.25 to $1 \mathrm{~g} / \mathrm{g}$, resulted in the almost complete consumption of glucose and also a doubling of cell density $\left(\mathrm{D}=0.3 \mathrm{~h}^{-1}\right.$ ), which led to an increase in volumetric $\mathrm{H}_{2}$ productivity $(20 \mathrm{mmol} / \mathrm{L} * \mathrm{~h})$. The $\mathrm{H}_{2}$ yield was, however, not affected [56]. This finding indicated that these observed changes in $\mathrm{H}_{2}$ yields were a function of the growth rate and did not depend on the substrate conversion efficiency. 


\subsection{End Product Inhibition and Osmotolerance}

Incomplete substrate conversions can also be observed in controlled batch fermentations with high initial substrate levels. Growth on $10 \mathrm{~g} / \mathrm{L}$ of both glucose and fructose resulted in complete substrate consumption, while higher initial substrate levels of glucose $(20$ and $31 \mathrm{~g} / \mathrm{L})$ and fructose $(20 \mathrm{~g} / \mathrm{L})$ resulted in incomplete conversions [55,91]. Similar observations were done for different sugar mixtures $[54,55,94]$. These incomplete conversions were attributed to the inhibitory effect of accumulating organic acids like acetate or lactate. Inhibition experiments showed that an acetate concentration of $200 \mathrm{mM}$ and higher prevented acid production by C. saccharolyticus grown on glucose $(10 \mathrm{~g} / \mathrm{L})$ in batch [91], which is in line with the earlier findings of van Niel et al., who observed critical sodium acetate and potassium acetate concentrations of $192 \mathrm{mM}$ and $206 \mathrm{mM}$, respectively, for batch growth on sucrose [73]. However, similar inhibitory effects were observed for $\mathrm{NaCl}$ and $\mathrm{KCl}$, with critical concentration of $216 \mathrm{mM}$ and $250 \mathrm{mM}$ respectively [73], suggesting that increased osmolarity is the cause of inhibition and not the end products per se. This relative low osmotolerance in comparison to marine organisms, like Thermotoga neapolitana [91], probably reflects the terrestrial origin of $C$. saccharolyticus. Ljunggren et al. designed a kinetic model for the growth of $C$. saccharolyticus incorporating the inhibitory effect of a high osmolarity and determined a critical osmolarity (no growth) in the range of 270 to $290 \mathrm{mM}$. They also showed that osmolarity is of minor influence on fermentations with low initial glucose levels [74]. This low tolerance to osmotic pressure also prevents the application of $\mathrm{CO}_{2}$ as a cheaper and more convenient stripping gas than $\mathrm{N}_{2}$. The use of $\mathrm{CO}_{2}$ as stripping gas during $C$. saccharolyticus cultivations negatively affects growth rate and hydrogen productivity. $\mathrm{CO}_{2}$ sparging led to a higher dissolved $\mathrm{CO}_{2}$ concentration, which required addition of extra base to maintain a constant $\mathrm{pH}$, overall leading to an increase in osmotic pressure [79].

\subsection{Medium Requirements}

Controlled batch cultivations were used to investigate the influence of $\mathrm{NH}_{4}{ }^{+}$on the performance of C. saccharolyticus grown on molasses. These experiments revealed that the omission of $\mathrm{NH}_{4}^{+}$gave rise to a higher $\mathrm{H}_{2}$ yield and maximal $\mathrm{H}_{2}$ productivity [90]. Although C. saccharolyticus is able to grow on a medium without $\mathrm{NH}_{4}{ }^{+}$, containing only $\mathrm{YE}$ as a nitrogen source, it becomes very sensitive to changes in $\mathrm{P}_{\mathrm{H} 2}$ ([77], Figure 4b). Chemostat cultivations showed complete glucose $(20.7 \mathrm{mM})$ consumption and high acetate yields $(1.87 \pm 0.02 \mathrm{~mol} / \mathrm{mol})$ under low $\mathrm{P}_{\mathrm{H} 2}$. However, when the cultivation condition changed to a high $\mathrm{P}_{\mathrm{H} 2}$ a new steady state could be achieved, but substrate consumption was incomplete (55\%) and acetate yields decreased $(1.68 \pm 0.01 \mathrm{~mol} / \mathrm{mol})$.

Omission of yeast extract (YE) during growth of $C$. saccharolyticus on molasses did not affect the $\mathrm{H}_{2}$ yield but led to a lower volumetric $\mathrm{H}_{2}$ productivity [90]. Similar observations were made for controlled batch fermentations on glucose, where the absence of YE did not affect the $\mathrm{H}_{2}$ and biomass yields [100]. Contrary to the molasses study the volumetric productivity was not affected [100] but this might be due to the lower substrate load used. C. saccharolyticus is able to grow on a defined minimal medium with additional vitamins, but without additional amino acids [100]. Growth in the absence of YE helps to reduce the production costs. However, increased biomass levels and especially growth on 
high substrate loads might augment medium requirements. So fine-tuning of the medium composition with respect to the specific substrate and substrate load is required.

\section{Future Prospects for Improving Biohydrogen Production}

\subsection{Improving $\mathrm{H}_{2}$ Yields and $\mathrm{H}_{2}$ Productivity}

C. saccharolyticus has many properties that make it an excellent candidate for biohydrogen production via dark fermentation. However, for biohydrogen production to become economically feasible major improvements should be made with respect to the $\mathrm{H}_{2}$ productivity [104-106]. Productivity is maximized by improving the substrate consumption rate but also the $\mathrm{H}_{2}$ yield.

C. saccharolyticus is able to produce $\mathrm{H}_{2}$ close to the theoretical maximum of $4 \mathrm{H}_{2}$ per hexose. In this respect, it is important to realize that the theoretical yield refers to the pure catabolic component of glucose conversion. The glucose used for anabolism should not be incorporated. Generally, this distinction is not considered in literature, and reported experimental data therefore reveal $\mathrm{H}_{2}$ yields lower than 4. For example, a yield of $3.5 \mathrm{H}_{2}$ per consumed glucose has been reported by de Vrije et al. (chemostat cultivation with a $23.0 \mathrm{mM}$ glucose load and a dilution rate of $0.1 \mathrm{~h}^{-1}$ ) [56]. According to their data $16 \%$ of the consumed glucose is used only for biomass formation indicating that only $\sim 19.4 \mathrm{mM}$ glucose was available for ATP generation. Given the reported $\mathrm{H}_{2}$ production this results in a theoretical conversion efficiency of $4.15 \mathrm{~mol} \mathrm{H}_{2}$ per mol glucose, which approximates the theoretical maximum of $4 \mathrm{H}_{2}$ per hexose as indicated by Thauer et al. [83]. These high yields are only achievable when the organism ferments the substrate solely to acetate. However, non-ideal growth conditions lead to a mixed fermentation profile (acetate, lactate and ethanol), and a consequently lower $\mathrm{H}_{2}$ yield. From the organism's perspective switching to lactate or ethanol is profitable since it allows the organism to continue to grow under elevated $\mathrm{P}_{\mathrm{H} 2}$ conditions, albeit with a lower growth rate because ATP yields are lower under lactate and ethanol forming conditions. Obviously, the lower $\mathrm{H}_{2}$ yield under a mixed end-product fermentation, is not desirable from a biotechnological point of view. To maximize the $\mathrm{H}_{2}$ yield and productivity, the dissolved $\mathrm{H}_{2}$ concentration should be kept as low as possible, which requires an optimization of the liquid to mass transfer rate $[74,76]$, which is mainly a matter of reactor design. In continuous stirred-tank reactor systems low dissolved $\mathrm{H}_{2}$ concentrations could be achieved by increasing the sparging rate [107,108] or the stirring speed [109,110]. In addition, reduction of internal reactor pressure [111-113] and enforced bubble formation [113,114] could potentially lead to a lower dissolved $\mathrm{H}_{2}$ concentration. Addition of zeolite particles, which enhances bubble formation, allowed a reduction of the $\mathrm{N}_{2}$ stripping rate from $5 \mathrm{~L} /\left(\mathrm{h}^{*} \mathrm{~L}\right)$ to $1 \mathrm{~L} /\left(\mathrm{h}^{*} \mathrm{~L}\right)$, without affecting the $\mathrm{H}_{2}$ productivity and $\mathrm{H}_{2}$ yield of $C$. saccharolyticus. $\mathrm{N}_{2}$ stripping could even be completely omitted when an internal reactor pressure of 0.3 bar was used, which sustained a similar fermentation performance compared to cultivation at atmospheric pressure (1 bar) using a $\mathrm{N}_{2}$ gas stripping rate of $5 \mathrm{~L} /(\mathrm{h} * \mathrm{~L})$ [113].

Most research on $C$. saccharolyticus has been performed in serum bottles and suspended continuous stirred-tank reactor systems, where only relatively low cell biomass levels can be achieved. Higher cell biomass levels would cause an increase in substrate consumption rates leading to an increase in $\mathrm{H}_{2}$ productivity when $\mathrm{H}_{2}$ yields are maintained. To realize higher biomass levels a deeper insight into growth limiting medium compounds should be acquired. Additionally, other reactor types, like a 
trickle bed reactor or a fluidized bed system might allow cell biomass accumulation. C. saccharolyticus could be cultivated in a non-axenic $400 \mathrm{~L}$ trickle bed reactor [102] out-competing other organisms, with $\mathrm{H}_{2}$ yields around $2.8 \mathrm{~mol} \mathrm{H}_{2} / \mathrm{mol}$ hexose and a productivity of $22 \mathrm{mmol} \mathrm{H}_{2} / \mathrm{L}^{*} \mathrm{~h}$. These results showed that $C$. saccharolyticus can be used in a large scale non-sterile industrial setting.

Combining different organisms in a co-cultivation setup allows the exploitation of the hydrolytic capability of each individual species and could enhance the overall range of useable substrates. Batch co-cultivations of $C$. saccharolyticus with either $C$. owensensis, $C$. kristjanssonii or an enriched compost microflora were performed on a glucose-xylose mixture [115]. The co-cultivation with the enriched compost microflora resulted in a fast, simultaneous consumption of both glucose and xylose with a relatively high specific hydrogen production rate, but with a lower $\mathrm{H}_{2}$ yield [115]. A stable co-culture consisting of two closely related Caldicellulosiruptor species, C. saccharolyticus and C. kristjanssonii, could be established in a continuous cultivation system [116]. These findings demonstrate the possibility to create co-cultures for $\mathrm{H}_{2}$ formation and reveal an apparent synergistic effect of the strains, which lead to improved fermentation performances.

Overall $\mathrm{H}_{2}$ yields from biomass derived substrates can be increased when the dark fermentation is coupled to a second stage like electrohydrogenesis or photofermentation [117,118]. The former system uses a microbial electrolysis cell (MEC), in which electricity is used to convert acetate or other organic acids to hydrogen. In the latter case the main end product of the dark fermentation, acetate, is further converted by an anaerobic non-sulfur purple photosynthetic bacterium, forming a maximum of 4 mol $\mathrm{H}_{2}$ per mol acetate, giving an overall $\mathrm{H}_{2}$ yield of $12 \mathrm{~mol} \mathrm{H}_{2}$ per mol glucose. The effluent of C. saccharolyticus has been successfully used as a feed for photofermentative growth and $\mathrm{H}_{2}$ production [90,119,120]. Alternatively, dark fermentation end-products $\mathrm{H}_{2}$ and acetate could serve as substrates for hydrogenothropic methanogens in a biogas generating system. The addition of C. saccharolyticus to natural biogas-producing consortia led to an improvement of biogas production and a stable co-cultivation could be maintained for several months [98].

\subsection{Genetic Engineering of Caldicellulosiruptor Species}

The first steps in the development of a genetic system for Caldicellulosiruptor species have been made. Chung et al. have shown that methylation with an endogenous unique $\alpha$-class N4-Cytosine methyltransferase is required for transformation of DNA isolated from E. coli into Caldicellulosiruptor bescii [121]. Furthermore, an uracil auxotrophic $C$. bescii mutant strain was generated by a spontaneous deletion in the pyrBCF locus [121]. This nutritional deficiency was exploited as a selection marker of $C$. bescii transformants [121]. A similar strategy might be applied to develop a genetic system for the other members of this genus.

To improve the $\mathrm{H}_{2}$ producing capabilities of $C$. saccharolyticus or other Caldicellulosiruptor species metabolic engineering strategies could focus on improving the $\mathrm{H}_{2}$ yields. Additionally it could be aimed at altering intrinsic properties of Caldicellulosiruptor species limiting $\mathrm{H}_{2}$ productivity like the enhancement of their $\mathrm{H}_{2}$ tolerance or osmotolerance. For example, for industrial applications increased substrate concentrations are favored since it reduces the fresh water demand, thus reducing the overall costs and the environmental impact of the process. However, for $C$. saccharolyticus the maximum substrate load is limited by its sensitivity to osmotic stress $[12,73,74]$. 
With respect to the mixed acid fermentation, both lactate and ethanol formations lead to a lowered $\mathrm{H}_{2}$ yield. Because ethanol formation is not the major reductant sink under redox stress and in general is only produced at low levels, knocking out the alcohol dehydrogenase responsible for ethanol formation will probably not significantly alter the fermentation performance of $C$. saccharolyticus. However, lactate formation can be seen as the main mechanism to alleviate redox stress. Targeting the lactate formation pathway for complete knockout will probably make C. saccharolyticus less resilient to fluctuations in dissolved $\mathrm{H}_{2}$ concentration and is inadvisable.

Alternatively, one could alter glycolysis in such a way that substrate conversion is less energy efficient. So to generate the same amount of ATP, essential for biosynthesis and maintenance, a higher glycolytic flux to acetate is required. This would result in a higher $\mathrm{H}_{2}$ yield because the glycolytic flux to acetate is increased with respect to the carbon flux to biomass. A less energy efficient glycolysis can be achieved by eliminating some ATP generating steps from the central metabolic pathway. For example, exchanging the NADH-dependent GAPDH in C. saccharolyticus with the ferredoxin-dependent GAPOR, would decrease the overall ATP yield of glycolysis. In addition, since the $\mathrm{H}_{2}$ formation from the generated $\mathrm{Fd}_{\text {red }}$ is energetically more favourable than $\mathrm{H}_{2}$ formation from $\mathrm{NADH}$, the organism would become less sensitive to increased $\mathrm{H}_{2}$ levels $[9,12]$.

$\mathrm{H}_{2}$ yields on rhamnose and fucose could be increased if the carbon flux from the intermediate lactaldehyde is redirected via methylglyoxal to pyruvate, by the insertion of a lactaldehyde dehydrogenase and a methylglyoxal dehydrogenase. When rhamnose is completely oxidized to acetate, via this pathway, the $\mathrm{H}_{2}$ yield increases from 1 to $5 \mathrm{H}_{2}$ per rhamnose. With respect to alternative substrates, glycerol could serve as a good substrate for $\mathrm{H}_{2}$ production because of the relative high reduced state of its carbon atoms. A maximum $\mathrm{H}_{2}$ yield of $3 \mathrm{~mol} / \mathrm{mol}$ glycerol is achieved if glycerol is completely oxidized to acetate. So far, growth or co-consumption on/of glycerol has, however, not been observed for $C$. saccharolyticus [122].

\section{Conclusions}

The bacterium Caldicellulosiruptor saccharolyticus possesses several features that make it an excellent candidate for biological hydrogen production. With an optimal growth temperature of $70{ }^{\circ} \mathrm{C}$ C. saccharolyticus is one of the most thermophilic cellulose degrading organisms known to date. The organisms diverse inventory of endo- and exo-glycoside hydrolases allow it to degrade and grow on a variety of cellulose- and hemicellulose-containing biomass substrates. Some of these glycosidases are multi-domain proteins that contain both glycoside hydrolase domains and carbon binding modules, which facilitate the efficient degradation of recalcitrant plant polysaccharides into mono-, di- or oligo-saccharides. The high diversity of transport systems present in the genome confirm the broad substrate preferences of $C$. saccharolyticus and its ability to co-utilization hexoses and pentoses, without any signs of carbon catabolite repression, is a desirable trait for any consolidated bioprocess.

For $C$. saccharolyticus sugar substrates are primarily fermented to acetate, $\mathrm{CO}_{2}$ and $\mathrm{H}_{2}$, via the Embden-Meyerhof pathway. Typically, the fermentation of hexose and pentose lead to the generation of the reduced electron carriers $\mathrm{NADH}$ and $\mathrm{Fd}_{\text {red }}$ in a 1:1 ratio. These reduced electron carriers can be reoxidized during two distinct $\mathrm{H}_{2}$ generating steps, respectively catalyzed by an NADH-dependent

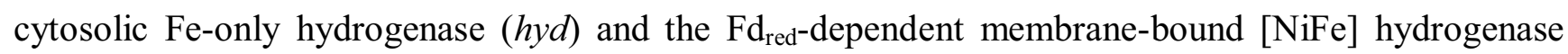


(ech). Alternatively, rhamnose catabolism is coupled to a different type of redox balancing, where the generated NADH is used for 1,2-propanediol formation and only the $\mathrm{Fd}_{\mathrm{red}}$ is available for $\mathrm{H}_{2}$ formation.

Fermentation data reveal that $C$. saccharolyticus is capable of producing $\mathrm{H}_{2}$ with yields close to the theoretical limit of $4 \mathrm{H}_{2}$ per hexose. However, under non-ideal conditions both ethanol and lactate formation act as alternative redox sinks, thus reducing $\mathrm{H}_{2}$ yields. All possible redox sinks, including the hydrogenases, are upregulated during cultivation under an increased partial hydrogen pressure. The mechanism underlying transcription of the lactate dehydrogenase gene remains elusive, but the transcription of the genes coding for both hydrogenases and the alcohol dehydrogenases, potentially involved in ethanol formation, seem to be under the control of an $\mathrm{NADH} / \mathrm{NAD}^{+}$-sensing transcriptional regulator REX.

An increased intracellular NADH/NAD ${ }^{+}$ratio, putatively caused by the inhibition of hydrogenase activity at elevated $\mathrm{H}_{2}$ levels, can hinder glycolysis at the level of glyceraldehyde-3-phosphate dehydrogenase, resulting in the inhibition of growth. Lactate formation serves as an alternative redox sink, alleviating redox stress. Lactate dehydrogenase activity is enhanced by the glycolytic intermediate fructose-1,6-bisphosphate but also modulated by the energy carriers ATP and pyrophosphate. The latter mechanism couples lactate formation to the energy metabolism, where lactate formation is inhibited during exponential growth and inhibition is alleviated during the transition to the stationary phase.

Overall, maintaining low dissolved $\mathrm{H}_{2}$ levels in the system appeared to be one of the most important factors for optimizing $\mathrm{H}_{2}$ production. In addition, improvements should be made with respect to the $\mathrm{H}_{2}$ productivity and osmotolerance of the organism to allow biohydrogen production by $C$. saccharolyticus to become economically feasible.

\section{Acknowledgments}

This research was supported by the IPOP program of Wageningen University and a grant from the 6th EU Framework Programme, Priority 6.1: Sustainable Energy Systems, contract 019825 (HYVOLUTION).

\section{References and Notes}

1. Lynd, L.R.; Wyman, C.E.; Gerngross, T.U. Biocommodity engineering. Biotechnol. Prog. 1999, 15, 777-793.

2. Lynd, L.R.; Zyl, W.H.V.; McBride, J.E.; Laser, M. Consolidated bioprocessing of cellulosic biomass: An update. Curr. Opin. Biotechnol. 2005, 16, 577-583.

3. Agbor, V.B.; Cicek, N.; Sparling, R.; Berlin, A.; Levin, D.B. Biomass pretreatment: Fundamentals toward application. Biotechnol. Adv. 2011, 29, 675-685.

4. Olson, D.G.; McBride, J.E.; Shaw, A.J.; Lynd, L.R. Recent progress in consolidated bioprocessing. Curr. Opin. Biotechnol. 2012, 23, 396-405.

5. Hallenbeck, P.C. Fermentative hydrogen production: Principles, progress, and prognosis. Int. J. Hydrogen Energy 2009, 34, 7379-7389.

6. Bergquist, P.L.; Gibbs, M.D.; Morris, D.D.; Te'o, V.S.; Saul, D.J.; Moran, H.W. Molecular diversity of thermophilic cellulolytic and hemicellulolytic bacteria. FEMS Microbiol. Ecol. 1999, 28, 99-110. 
7. Blumer-Schuette, S.E.; Kataeva, I.; Westpheling, J.; Adams, M.W.W.; Kelly, R.M. Extremely thermophilic microorganisms for biomass conversion: Status and prospects. Curr. Opin. Biotechnol. 2008, 19, 210-217.

8. VanFossen, A.L.; Lewis, D.L.; Nichols, J.D.; Kelly, R.M. Polysaccharide degradation and synthesis by extremely thermophilic anaerobes. Incredible Anaerobes Physiol. Genomics Fuels 2008, 1125, 322-337.

9. Kengen, S.W.M.; Goorissen, H.P.; Verhaart, M.R.A.; Stams, A.J.M.; van Niel, E.W.J.; Claassen, P.A.M. Biological hydrogen production by anaerobic microorganisms. In Biofuels, Soetaert, W., Verdamme, E.J., Eds.; John Wiley \& Sons: Chichester, UK, 2009; pp. 197-221.

10. Verhaart, M.R.A.; Bielen, A.A.M.; van der Oost, J.; Stams, A.J.M.; Kengen, S.W.M. Hydrogen production by hyperthermophilic and extremely thermophilic bacteria and archaea: Mechanisms for reductant disposal. Environ. Technol. 2010, 31, 993-1003.

11. De Vrije, T.; Claasen, P.A.M. Dark hydrogen fermentations. In Bio-methane \& Bio-hydrogen, Reith, J.H., Wijffels, R.H., Barten, H., Eds.; Smiet Offset: The Hague, The Netherlands, 2003; pp. 103-123.

12. Willquist, K.; Zeidan, A.A.; van Niel, E.W. Physiological characteristics of the extreme thermophile Caldicellulosiruptor saccharolyticus: An efficient hydrogen cell factory. Microb. Cell Fact. 2010, 9, 89.

13. Rainey, F.A.; Donnison, A.M.; Janssen, P.H.; Saul, D.; Rodrigo, A.; Bergquist, P.L.; Daniel, R.M.; Stackebrandt, E.; Morgan, H.W. Description of Caldicellulosiruptor saccharolyticus gen. nov., sp. nov: An obligately anaerobic, extremely thermophilic, cellulolytic bacterium. FEMS Microbiol. Lett. 1994, 120, 263-266.

14. Sissons, C.H.; Sharrock, K.R.; Daniel, R.M.; Morgan, H.W. Isolation of cellulolytic anaerobic extreme thermophiles from New Zealand thermal sites. Appl. Environ. Microbiol. 1987, 53, 832-838.

15. Reynolds, P.H.S.; Sissons, C.H.; Daniel, R.M.; Morgan, H.W. Comparison of cellulolytic activities in Clostridium thermocellum and three thermophilic, cellulolytic anaerobes. Appl. Environ. Microbiol. 1986, 51, 12-17.

16. Donnison, A.M.; Brockelsby, C.M.; Morgan, H.W.; Daniel, R.M. The degradation of lignocellulosics by extremely thermophilic microorganisms. Biotechnol. Bioeng. 1989, 33, 1495-1499.

17. Bredholt, S.; Sonne-Hansen, J.; Nielsen, P.; Mathrani, I.M.; Ahring, B.K. Caldicellulosiruptor kristjanssonii sp. nov., a cellulolytic extremely thermophilic, anaerobic bacterium. Int. J. Syst. Bacteriol. 1999, 49, 991-996.

18. Dwivedi, P.P.; Gibbs, M.D.; Saul, D.J.; Bergquist, P.L. Cloning, sequencing and overexpression in Escherichia coli of a xylanase gene, xynA from the thermophilic bacterium Rt8B.4 genus Caldicellulosiruptor. Appl. Microbiol. Biotechnol. 1996, 45, 86-93.

19. Gibbs, M.D.; Reeves, R.A.; Farrington, G.K.; Anderson, P.; Williams, D.P.; Bergquist, P.L. Multidomain and multifunctional glycosyl hydrolases from the extreme thermophile Caldicellulosiruptor isolate Tok7B.1. Curr. Microbiol. 2000, 40, 333-340.

20. Hamilton-Brehm, S.D.; Mosher, J.J.; Vishnivetskaya, T.; Podar, M.; Carroll, S.; Allman, S.; Phelps, T.J.; Keller, M.; Elkins, J.G. Caldicellulosiruptor obsidiansis sp. nov., an anaerobic, 
extremely thermophilic, cellulolytic bacterium isolated from Obsidian pool, Yellowstone national park. Appl. Environ. Microbiol. 2010, 76, 1014-1020.

21. Huang, C.Y.; Patel, B.K.; Mah, R.A.; Baresi, L. Caldicellulosiruptor owensensis sp. nov., an anaerobic, extremely thermophilic, xylanolytic bacterium. Int. J. Syst. Bacteriol. 1998, 48, 91-97.

22. Miroshnichenko, M.L.; Kublanov, I.V.; Kostrikina, N.A.; Tourova, T.P.; Kolganova, T.V.; Birkeland, N.K.; Bonch-Osmolovskaya, E.A. Caldicellulosiruptor kronotskyensis sp. nov. and Caldicellulosiruptor hydrothermalis sp. nov., two extremely thermophilic, cellulolytic, anaerobic bacteria from Kamchatka thermal springs. Int. J. Syst. Evol. Microbiol. 2008, 58, 1492-1496.

23. Mladenovska, Z.; Mathrani, I.M.; Ahring, B.K. Isolation and characterization of Caldicellulosiruptor lactoaceticus sp. nov., an extremely thermophilic, cellulolytic, anaerobic bacterium. Arch. Microbiol. 1995, 163, 223-230.

24. Morris, D.D.; Gibbs, M.D.; Ford, M.; Thomas, J.; Bergquist, P.L. Family 10 and 11 xylanase genes from Caldicellulosiruptor sp. strain Rt69B.1. Extremophiles 1999, 3, 103-111.

25. Nielsen, P.; Mathrani, I.M.; Ahring, B.K. Thermoanaerobium acetigenum spec. nov., a new anaerobic, extremely thermophilic, xylanolytic non-spore-forming bacterium isolated from an Icelandic hot spring. Arch. Microbiol. 1993, 159, 460-464.

26. Onyenwoke, R.U.; Lee, Y.J.; Dabrowski, S.; Ahring, B.K.; Wiegel, J. Reclassification of "Thermoanaerobium acetigenum" as Caldicellulosiruptor acetigenus comb. nov and emendation of the genus description. Int. J. Syst. Evol. Microbiol. 2006, 56, 1391-1395.

27. Svetlichnyi, V.A.; Svetlichnaya, T.P.; Chernykh, N.A.; Zavarzin, G.A. Anaerocellum thermophilum gen. nov. sp. nov.: An extremely thermophilic cellulolytic eubacterium isolated from hot-springs in the Valley of Geysers. Microbiology 1990, 59, 598-604.

28. Yang, S.J.; Kataeva, I.; Wiegel, J.; Yin, Y.; Dam, P.; Xu, Y.; Westpheling, J.; Adams, M.W. Reclassification of "Anaerocellum thermophilum" as Caldicellulosiruptor bescii strain DSM 6725T sp. nov. Int. J. Syst. Evol. Microbiol. 2009, 60, 2011-2015.

29. Blumer-Schuette, S.E.; Giannone, R.J.; Zurawski, J.V.; Ozdemir, I.; Ma, Q.; Yin, Y.B.; Xu, Y.; Kataeva, I.; Poole, F.L.; Adams, M.W.W.; et al. Caldicellulosiruptor core and pangenomes reveal determinants for noncellulosomal thermophilic deconstruction of plant biomass. J. Bacteriol. 2012, 194, 4015-4028.

30. Blumer-Schuette, S.E.; Ozdemir, I.; Mistry, D.; Lucas, S.; Lapidus, A.; Cheng, J.F.; Goodwin, L.A.; Pitluck, S.; Land, M.L.; Hauser, L.J.; et al. Complete genome sequences for the anaerobic, extremely thermophilic plant biomass-degrading bacteria Caldicellulosiruptor hydrothermalis, Caldicellulosiruptor kristjanssonii, Caldicellulosiruptor kronotskyensis, Caldicellulosiruptor owensensis, and Caldicellulosiruptor lactoaceticus. J. Bacteriol. 2011, 193, 1483-1484.

31. Elkins, J.G.; Lochner, A.; Hamilton-Brehm, S.D.; Davenport, K.W.; Podar, M.; Brown, S.D.; Land, M.L.; Hauser, L.J.; Klingeman, D.M.; Raman, B.; et al. Complete genome sequence of the cellulolytic thermophile Caldicellulosiruptor obsidiansis OB47T. J. Bacteriol. 2010, 192, 6099-6100.

32. Kataeva, I.A.; Yang, S.J.; Dam, P.; Poole, F.L.; Yin, Y.; Zhou, F.F.; Chou, W.C.; Xu, Y.; Goodwin, L.; Sims, D.R.; et al. Genome sequence of the anaerobic, thermophilic, and cellulolytic bacterium “Anaerocellum thermophilum” DSM 6725. J. Bacteriol. 2009, 191, 3760-3761. 
33. Van de Werken, H.J.G.; Verhaart, M.R.A.; VanFossen, A.L.; Willquist, K.; Lewis, D.L.; Nichols, J.D.; Goorissen, H.P.; Mongodin, E.F.; Nelson, K.E.; van Niel, E.W.J., et al. Hydrogenomics of the extremely thermophilic bacterium Caldicellulosiruptor saccharolyticus. Appl. Environ. Microbiol. 2008, 74, 6720-6729.

34. Lamed, R.; Bayer, E.A. The cellulosome of Clostridium thermocellum. Adv. Appl. Microbiol. 1988, 33, 1-46.

35. Blumer-Schuette, S.E.; Lewis, D.L.; Kelly, R.M. Phylogenetic, microbiological, and glycoside hydrolase diversities within the extremely thermophilic, plant biomass-degrading genus Caldicellulosiruptor. Appl. Environ. Microbiol. 2010, 76, 8084-8092.

36. VanFossen, A.L.; Ozdemir, I.; Zelin, S.L.; Kelly, R.M. Glycoside hydrolase inventory drives plant polysaccharide deconstruction by the extremely thermophilic bacterium Caldicellulosiruptor saccharolyticus. Biotechnol. Bioeng. 2011, 108, 1559-1569.

37. Bergquist, P.L.; Love, D.R.; Croft, J.E.; Streiff, M.B.; Daniel, R.M.; Morgan, W.H. Genetics and potential biotechnological applications of thermophilic and extremely thermophilic microorganisms. Biotechnol. Genet. Eng. Rev. 1987, 5, 199-244.

38. Love, D.R.; Streiff, M.B. Molecular cloning of a beta-glucosidase gene from an extremely thermophilic anaerobe in Escherichia coli and Bacillus subtilis. BioTechnology 1987, 5, 384-387.

39. Hudson, R.C.; Schofield, L.R.; Coolbear, T.; Daniel, R.M.; Morgan, H.W. Purification and properties of an aryl beta-xylosidase from a cellulolytic extreme thermophile expressed in Escherichia coli. Biochem. J. 1991, 273, 645-650.

40. Schofield, L.R.; Daniel, R.M. Purification and properties of a beta-1,4-xylanase from a cellulolytic extreme thermophile expressed in Escherichia coli. Int. J. Biochem. 1993, 25, 609-617.

41. Albertson, G.D.; McHale, R.H.; Gibbs, M.D.; Bergquist, P.L. Cloning and sequence of a type I pullulanase from an extremely thermophilic anaerobic bacterium, Caldicellulosiruptor saccharolyticus. Biochimica Et Biophysica Acta-Gene Structure and Expression 1997, 1354, 35-39.

42. Luthi, E.; Jasmat, N.B.; Bergquist, P.L. Xylanase from the extremely thermophilic bacterium "Caldocellum saccharolyticum": Overexpression of the gene in Escherichia coli and characterization of the gene product. Appl. Environ. Microbiol. 1990, 56, 2677-2683.

43. Luthi, E.; Bergquist, P.L. A beta-D-xylosidase from the thermophile "Caldocellum saccharolyticum" expressed in Escherichia coli. FEMS Microbiol. Lett. 1990, 67, 291-294.

44. Luthi, E.; Jasmat, N.B.; Bergquist, P.L. Overproduction of an acetylxylan esterase from the extreme thermophile "Caldocellum saccharolyticum" in Escherichia coli. Appl. Microbiol. Biotechnol. 1990, 34, 214-219.

45. Te'o, V.S.J.; Saul, D.J.; Bergquist, P.L. Cela, another gene coding for a multidomain cellulase from the extreme thermophile "Caldocellum saccharolyticum". Appl. Microbiol. Biotechnol. 1995, 43, 291-296.

46. Park, C.S.; Kim, J.E.; Choi, J.G.; Oh, D.K. Characterization of a recombinant cellobiose 2-epimerase from Caldicellulosiruptor saccharolyticus and its application in the production of mannose from glucose. Appl. Microbiol. Biotechnol. 2011, 92, 1187-1196. 
47. Saul, D.J.; Williams, L.C.; Grayling, R.A.; Chamley, L.W.; Love, D.R.; Bergquist, P.L. Celb, a gene coding for a bifunctional cellulase from the extreme thermophile "Caldocellum saccharolyticum". Appl. Environ. Microbiol. 1990, 56, 3117-3124.

48. Morris, D.D.; Reeves, R.A.; Gibbs, M.D.; Saul, D.J.; Bergquist, P.L. Correction of the beta-mannanase domain of the Celc pseudogene from Caldocellulosiruptor saccharolyticus and activity of the gene product on Kraft pulp. Appl. Environ. Microbiol. 1995, 61, 2262-2269.

49. Luthi, E.; Jasmat, N.B.; Grayling, R.A.; Love, D.R.; Bergquist, P.L. Cloning, sequence analysis, and expression in Escherichia coli of a gene coding for a beta-mannanase from the extremely thermophilic bacterium "Caldocellum saccharolyticum". Appl. Environ. Microbiol. 1991, 57, 694-700.

50. Andrews, G.; Lewis, D.; Notey, J.; Kelly, R.; Muddiman, D. Part I: Characterization of the extracellular proteome of the extreme thermophile Caldicellulosiruptor saccharolyticus by GeLC-MS2 (vol 398, pg 377, 2010). Anal. Bioanal. Chem. 2010, 398, 1837-1837.

51. Ozdemir, I.; Blumer-Schuette, S.E.; Kelly, R.M. S-Layer homology domain proteins Csac_0678 and Csac_2722 are implicated in plant polysaccharide deconstruction by the extremely thermophilic bacterium Caldicellulosiruptor saccharolyticus. Appl. Environ. Microbiol. 2012, $78,768-777$.

52. Ivanova, G.; Rakhely, G.; Kovacs, K.L. Hydrogen production from biopolymers by Caldicellulosiruptor saccharolyticus and stabilization of the system by immobilization. Int.l J. Hydrogen Energy 2008, 33, 6953-6961.

53. VanFossen, A.L.; Verhaart, M.R.A.; Kengen, S.M.W.; Kelly, R.M. Carbohydrate utilization patterns for the extremely thermophilic bacterium Caldicellulosiruptor saccharolyticus reveal broad growth substrate preferences. Appl. Environ. Microbiol. 2009, 75, 7718-7724.

54. De Vrije, T.; Bakker, R.R.; Budde, M.A.; Lai, M.H.; Mars, A.E.; Claassen, P.A. Efficient hydrogen production from the lignocellulosic energy crop Miscanthus by the extreme thermophilic bacteria Caldicellulosiruptor saccharolyticus and Thermotoga neapolitana. Biotechnol. Biofuels 2009, 2, 12.

55. De Vrije, T.; Budde, M.A.W.; Lips, S.J.; Bakker, R.R.; Mars, A.E.; Claassen, P.A.M. Hydrogen production from carrot pulp by the extreme thermophiles Caldicellulosiruptor saccharolyticus and Thermotoga neapolitana. Int. J. Hydrogen Energy 2010, 35, 13206-13213.

56. De Vrije, T.; Mars, A.E.; Budde, M.A.W.; Lai, M.H.; Dijkema, C.; de Waard, P.; Claassen, P.A.M. Glycolytic pathway and hydrogen yield studies of the extreme thermophile Caldicellulosiruptor saccharolyticus. Appl. Microbiol. Biotechnol. 2007, 74, 1358-1367.

57. Willquist, K.; van Niel, E.W.J. Lactate formation in Caldicellulosiruptor saccharolyticus is regulated by the energy carriers pyrophosphate and ATP. Metab. Eng. 2010, 12, 282-290.

58. Brown, S.D.; Guss, A.M.; Karpinets, T.V.; Parks, J.M.; Smolin, N.; Yang, S.H.; Land, M.L.; Klingeman, D.M.; Bhandiwad, A.; Rodriguez, M.; et al. Mutant alcohol dehydrogenase leads to improved ethanol tolerance in Clostridium thermocellum. Proc. Natl. Acad. Sci. USA 2011, 108, 13752-13757.

59. Peng, H.; Wu, G.G.; Shao, W.L. The aldehyde/alcohol dehydrogenase (AdhE) in relation to the ethanol formation in Thermoanaerobacter ethanolicus JW200. Anaerobe 2008, 14, 125-127. 
60. Bielen, A.A.M.; Verhaart, M.R.A.; VanFossen, A.L.; Blumer-Schuette, S.E.; Stams, A.J.M.; van der Oost, J.; Kelly, R.M.; Kengen, S.M.W. A thermophile under pressure:Transcriptional analysis of the response of Caldicellulosiruptor saccharolyticus to different $\mathrm{H}_{2}$ partial pressures. Int. J. Hydrogen Energy 2012, in press.

61. Ma, K.; Hutchins, A.; Sung, S.J.S.; Adams, M.W.W. Pyruvate ferredoxin oxidoreductase from the hyperthermophilic archaeon, Pyrococcus furiosus, functions as a CoA-dependent pyruvate decarboxylase. Proc. Natl. Acad. Sci. USA 1997, 94, 9608-9613.

62. Kannan, V.; Mutharasan, R. Ethanol fermentation characteristics of Thermoanaerobacter ethanolicus. Enzyme. Microb. Technol. 1985, 7, 87-89.

63. Desai, S.G.; Guerinot, M.L.; Lynd, L.R. Cloning of L-lactate dehydrogenase and elimination of lactic acid production via gene knockout in Thermoanaerobacterium saccharolyticum JW/SL-YS485. Appl. Microbiol. Biotechnol. 2004, 65, 600-605.

64. Soboh, B.; Linder, D.; Hedderich, R. A multisubunit membrane-bound [NiFe] hydrogenase and an NADH-dependent Fe-only hydrogenase in the fermenting bacterium Thermoanaerobacter tengcongensis. Microbiology 2004, 150, 2451-2463.

65. Ma, K.S.; Adams, M.W.W. An unusual oxygen-sensitive, iron- and zinc-containing alcohol dehydrogenase from the hyperthermophilic archaeon Pyrococcus furiosus. J. Bacteriol. 1999, 181, 1163-1170.

66. Verhaart, M.R.A. Wageningen University, Wageningen, The Netherlands. Unpublished work, 2010.

67. DeLacey, A.L.; Stadler, C.; Fernandez, V.M.; Hatchikian, E.C.; Fan, H.J.; Li, S.H.; Hall, M.B. IR spectroelectrochemical study of the binding of carbon monoxide to the active site of Desulfovibrio fructosovorans Ni-Fe hydrogenase. J. Biol. Inorg. Chem. 2002, 7, 318-326.

68. Lemon, B.J.; Peters, J.W. Binding of exogenously added carbon monoxide at the active site of the iron-only hydrogenase $(\mathrm{CpI})$ from Clostridium pasteurianum. Biochemistry 1999, 38, 12969-12973.

69. Heinonen, J.K. Biological production of PPi. In Biological Role of Inorganic Pyrophosphate; Heinonen, J.K., Ed.; Kluwer Academic Publishers: Boston, MA, USA, Dordrecht, The Netherlands, London, UK, 2001; p. 264.

70. Chen, J.; Brevet, A.; Fromant, M.; Leveque, F.; Schmitter, J.M.; Blanquet, S.; Plateau, P. Pyrophosphatase is essential for growth of Escherichia coli. J. Bacteriol. 1990, 172, 5686-5689.

71. Bielen, A.A.M.; Willquist, K.; Engman, J.; van der Oost, J.; van Niel, E.W.J.; Kengen, S.W.M. Pyrophosphate as a central energy carrier in the hydrogen-producing extremely thermophilic Caldicellulosiruptor saccharolyticus. FEMS Microbiol. Lett. 2010, 307, 48-54.

72. Mertens, E. Pyrophosphate-dependent phosphofructokinase, an anaerobic glycolytic enzyme? FEBS Lett. 1991, 285, 1-5.

73. Van Niel, E.W.J.; Claassen, P.A.M.; Stams, A.J.M. Substrate and product inhibition of hydrogen production by the extreme thermophile, Caldicellulosiruptor saccharolyticus. Biotechnol. Bioeng. 2003, 81, 255-262.

74. Ljunggren, M.; Willquist, K.; Zacchi, G.; van Niel, E.W.J. A kinetic model for quantitative evaluation of the effect of hydrogen and osmolarity on hydrogen production by Caldicellulosiruptor saccharolyticus. Biotechnol. Biofuels 2011, 4, 31. 
75. Willquist, K.; Pawar, S.S.; van Niel, E.W.J. Reassessment of hydrogen tolerance in Caldicellulosiruptor saccharolyticus. Microb. Cell Fact. 2011, 10, 111.

76. Kraemer, J.T.; Bagley, D.M. Supersaturation of dissolved $\mathrm{H}_{2}$ and $\mathrm{CO}_{2}$ during fermentative hydrogen production with $\mathrm{N}_{2}$ sparging. Biotechnol. Lett. 2006, 28, 1485-1491.

77. Bielen, A.A.M. Wageningen University, Wageningen, The Netherlands. Unpublished work, 2012.

78. Kadar, Z.; de Vrijek, T.; van Noorden, G.E.; Budde, M.A.W.; Szengyel, Z.; Reczey, K.; Claassen, P.A.M. Yields from glucose, xylose, and paper sludge hydrolysate during hydrogen production by the extreme thermophile Caldicellulosiruptor saccharolyticus. Appl. Biochem. Biotechnol. 2004, 113-116, 497-508.

79. Willquist, K.; Claassen, P.A.M.; van Niel, E.W.J. Evaluation of the influence of $\mathrm{CO}_{2}$ on hydrogen production by Caldicellulosiruptor saccharolyticus. Int. J. Hydrogen Energy 2009, 34, 4718-4726.

80. Amend, J.P.; Plyasunov, A.V. Carbohydrates in thermophile metabolism: Calculation of the standard molal thermodynamic properties of aqueous pentoses and hexoses at elevated temperatures and pressures. Geochim. Cosmochim. Acta 2001, 65, 3901-3917.

81. Amend, J.P.; Shock, E.L. Energetics of overall metabolic reactions of thermophilic and hyperthermophilic Archaea and Bacteria. FEMS Microbiol. Rev. 2001, 25, 175-243.

82. Burton, K. Enthalpy change for reduction of nicotinamide-adenine dinucleotide. Biochem. J. 1974, 143, 365-368.

83. Thauer, R.K.; Jungermann, K.; Decker, K. Energy-conservation in chemotropic anaerobic bacteria. Bacteriol. Rev. 1977, 41, 100-180.

84. Watt, G.D.; Burns, A. Thermochemical characterization of sodium dithionite, flavin mononucleotide, flavin-adenine dinucleotide and methyl and benzyl viologens as low-potential reductants for biological-systems. Biochem. J. 1975, 152, 33-37.

85. Biegel, E.; Schmidt, S.; Gonzalez, J.M.; Muller, V. Biochemistry, evolution and physiological function of the Rnf complex, a novel ion-motive electron transport complex in prokaryotes. Cell. Mol. Life Sci. 2011, 68, 613-634.

86. Schut, G.J.; Adams, M.W.W. The iron-hydrogenase of Thermotoga maritima utilizes ferredoxin and NADH synergistically: A new perspective on anaerobic hydrogen production. J. Bacteriol. 2009, 191, 4451-4457.

87. Panagiotopoulos, I.A.; Bakker, R.R.; de Vrije, T.; Claassen, P.A.M.; Koukios, E.G. Integration of first and second generation biofuels: Fermentative hydrogen production from wheat grain and straw. Bioresour. Technol. 2013, 128, 345-350.

88. Panagiotopoulos, I.A.; Bakker, R.R.; de Vrije, T.; Claassen, P.A.M.; Koukios, E.G. Dilute-acid pretreatment of barley straw for biological hydrogen production using Caldicellulosiruptor saccharolyticus. Int. J. Hydrogen Energy 2012, 37, 11727-11734.

89. Panagiotopoulos, I.; Barker, R.; de Vrije, T.; Niel, E.V.; Koukios, E.; Claassen, P. Exploring critical factors for fermentative hydrogen production from various types of lignocellulosic biomass. J. Jpn. Inst. Energy 2011, 90, 363-368.

90. Özgür, E.; Mars, A.E.; Peksel, B.; Louwerse, A.; Yücel, M.; Gündüz, U.; Claassen, P.A.M.; Eroğlu, I. Biohydrogen production from beet molasses by sequential dark and photofermentation. Int. J. Hydrogen Energy 2010, 35, 511-517. 
91. Mars, A.E.; Veuskens, T.; Budde, M.A.W.; van Doeveren, P.; Lips, S.J.; Bakker, R.R.; de Vrije, T.; Claassen, P.A.M. Biohydrogen production from untreated and hydrolyzed potato steam peels by the extreme thermophiles Caldicellulosiruptor saccharolyticus and Thermotoga neapolitana. Int. J. Hydrogen Energy 2010, 35, 7730-7737.

92. Herbel, Z.; Rakhely, G.; Bagi, Z.; Ivanova, G.; Acs, N.; Kovacs, E.; Kovacs, K.L. Exploitation of the extremely thermophilic Caldicellulosiruptor saccharolyticus in hydrogen and biogas production from biomasses. Environ. Technol. 2010, 31, 1017-1024.

93. Panagiotopoulos, J.A.; Bakker, R.R.; de Vrije, T.; Urbaniec, K.; Koukios, E.G.; Claassen, P.A.M. Prospects of utilization of sugar beet carbohydrates for biological hydrogen production in the EU. J. Cleaner Prod. 2010, 18, S9-S14.

94. Panagiotopoulos, I.A.; Bakker, R.R.; de Vrije, T.; Koukios, E.G.; Claassen, P.A.M. Pretreatment of sweet sorghum bagasse for hydrogen production by Caldicellulosiruptor saccharolyticus. Int. J. Hydrogen Energy 2010, 35, 7738-7747.

95. Yang, S.J.; Kataeva, I.; Hamilton-Brehm, S.D.; Engle, N.L.; Tschaplinski, T.J.; Doeppke, C.; Davis, M.; Westpheling, J.; Adams, M.W.W. Efficient degradation of lignocellulosic plant biomass, without pretreatment, by the thermophilic anaerobe "Anaerocellum thermophilum" DSM 6725. Appl. Environ. Microbiol. 2009, 75, 4762-4769.

96. Panagiotopoulos, I.A.; Bakker, R.R.; Budde, M.A.W.; de Vrije, T.; Claassen, P.A.M.; Koukios, E.G. Fermentative hydrogen production from pretreated biomass: A comparative study. Bioresour. Technol. 2009, 100, 6331-6338.

97. Ivanova, G.; Rakhely, G.; Kovacs, K.L. Thermophilic biohydrogen production from energy plants by Caldicellulosiruptor saccharolyticus and comparison with related studies. Int. J. Hydrogen Energy 2009, 34, 3659-3670.

98. Bagi, Z.; Acs, N.; Balint, B.; Horvath, L.; Dobo, K.; Perei, K.R.; Rakhely, G.; Kovacs, K.L. Biotechnological intensification of biogas production. Appl. Microbiol. Biotechnol. 2007, 76, 473-482.

99. Kadar, Z.; de Vrije, T.; Budde, M.A.; Szengyel, Z.; Reczey, K.; Claassen, P.A. Hydrogen production from paper sludge hydrolysate. Appl. Biochem. Biotechnol. 2003, 105-108, 557-566.

100. Willquist, K.; van Niel, E.W.J. Growth and hydrogen production characteristics of Caldicellulosiruptor saccharolyticus on chemically defined minimal media. Int. J. Hydrogen Energy 2012, 37, 4925-4929.

101. Muddiman, D.; Andrews, G.; Lewis, D.; Notey, J.; Kelly, R. Part II: Defining and quantifying individual and co-cultured intracellular proteomes of two thermophilic microorganisms by GeLC-MS(2) and spectral counting. Anal. Bioanal. Chem. 2010, 398, 391-404.

102. Van Groenestijn, J.W.; Geelhoed, J.S.; Goorissen, H.P.; Meesters, K.P.; Stams, A.J.; Claassen, P.A. Performance and population analysis of a non-sterile trickle bed reactor inoculated with Caldicellulosiruptor saccharolyticus, a thermophilic hydrogen producer. Biotechnol. Bioeng. 2009, 102, 1361-1367.

103. Van Niel, E.W.J.; Budde, M.A.W.; de Haas, G.G.; van der Wal, F.J.; Claasen, P.A.M.; Stams, A.J.M. Distinctive properties of high hydrogen producing extreme thermophiles, Caldicellulosiruptor saccharolyticus and Thermotoga elfii. Int. J. Hydrogen Energy 2002, 27, 1391-1398. 
104. Ljunggren, M.; Wallberg, O.; Zacchi, G. Techno-economic comparison of a biological hydrogen process and a 2nd generation ethanol process using barley straw as feedstock. Bioresour. Technol. 2011, 102, 9524-9531.

105. Ljunggren, M.; Zacchi, G. Techno-economic evaluation of a two-step biological process for hydrogen production. Biotechnol. Prog. 2010, 26, 496-504.

106. Nath, K.; Das, D. Improvement of fermentative hydrogen production: Various approaches. Appl. Microbiol. Biotechnol. 2004, 65, 520-529.

107. Kim, D.H.; Han, S.K.; Kim, S.H.; Shin, H.S. Effect of gas sparging on continuous fermentative hydrogen production. Int. J. Hydrogen Energy 2006, 31, 2158-2169.

108. Kraemer, J.T.; Bagley, D.M. Optimisation and design of nitrogen-sparged fermentative hydrogen production bioreactors. Int. J. Hydrogen Energy 2008, 33, 6558-6565.

109. Clark, I.C.; Zhang, R.H.H.; Upadhyaya, S.K. The effect of low pressure and mixing on biological hydrogen production via anaerobic fermentation. Int. J. Hydrogen Energy 2012, 37, 11504-11513.

110. Lamed, R.J.; Lobos, J.H.; Su, T.M. Effects of stirring and hydrogen on fermentation products of Clostridium thermocellum. Appl. Environ. Microbiol. 1988, 54, 1216-1221.

111. Junghare, M.; Subudhi, S.; Lal, B. Improvement of hydrogen production under decreased partial pressure by newly isolated alkaline tolerant anaerobe, Clostridium butyricum TM-9A: Optimization of process parameters. Int. J. Hydrogen Energy 2012, 37, 3160-3168.

112. Mandal, B.; Nath, K.; Das, D. Improvement of biohydrogen production under decreased partial pressure of $\mathrm{H}_{2}$ by Enterobacter cloacae. Biotechnol. Lett. 2006, 28, 831-835.

113. Sonnleitner, A.; Peintner, C.; Wukovits, W.; Friedl, A.; Schnitzhofer, W. Process investigations of extreme thermophilic fermentations for hydrogen production: Effect of bubble induction and reduced pressure. Bioresour. Technol. 2012, 118, 170-176.

114. Fritsch, M.; Hartmeier, W.; Chang, J.S. Enhancing hydrogen production of Clostridium butyricum using a column reactor with square-structured ceramic fittings. Int. J. Hydrogen Energy 2008, 33, 6549-6557.

115. Zeidan, A.A.; van Niel, E.W.J. Developing a thermophilic hydrogen-producing co-culture for efficient utilization of mixed sugars. Int. J. Hydrogen Energy 2009, 34, 4524-4528.

116. Zeidan, A.A.; van Niel, E.W.J. A quantitative analysis of hydrogen production efficiency of the extreme thermophile Caldicellulosiruptor owensensis OL(T). Int. J. Hydrogen Energy 2010, 35, 1128-1137.

117. Claassen, P.A.M.; de Vrije, T. Non-thermal production of pure hydrogen from biomass: HYVOLUTION. Int. J. Hydrogen Energy 2006, 31, 1416-1423.

118. Liu, H.; Grot, S.; Logan, B.E. Electrochemically assisted microbial production of hydrogen from acetate. Environ. Sci. Technol. 2005, 39, 4317-4320.

119. Özkan, E.; Uyar, B.; Özgür, E.; Yücel, M.; Eroğlu, I.; Gündüz, U. Photofermentative hydrogen production using dark fermentation effluent of sugar beet thick juice in outdoor conditions. Int. J. Hydrogen Energy 2012, 37, 2044-2049.

120. Özgür, E.; Afsar, N.; de Vrije, T.; Yücel, M.; Gündüz, U.; Claassen, P.A.M.; Eroğlu, I. Potential use of thermophilic dark fermentation effluents in photofermentative hydrogen production by Rhodobacter capsulatus. J. Cleaner Prod. 2010, 18, S23-S28. 
121. Chung, D.; Farkas, J.; Huddleston, J.R.; Olivar, E.; Westpheling, J. Methylation by a unique $\alpha$-class N4-Cytosine methyltransferase is required for DNA transformation of Caldicellulosiruptor bescii DSM6725. PLoS One 2012, 7, e43844.

122. Bielen, A.A.M. Wageningen University, Wageningen, The Netherlands. Unpublished work, 2009.

(C) 2013 by the authors; licensee MDPI, Basel, Switzerland. This article is an open access article distributed under the terms and conditions of the Creative Commons Attribution license (http://creativecommons.org/licenses/by/3.0/). 